\title{
Licensing adaptive immunity by NOD-like receptors
}

\author{
Dong Liu ${ }^{1,2,3}$, Anne Marie Rhebergen ${ }^{1,2,3}$ and Stephanie C. Eisenbarth ${ }^{1,2,3} *$ \\ 1 Department of Laboratory Medicine, Yale University School of Medicine, New Haven, CT, USA \\ 2 Department of Immunobiology, Yale University School of Medicine, New Haven, CT, USA \\ ${ }^{3}$ Department of Internal Medicine, Yale University School of Medicine, New Haven, CT, USA
}

\section{Edited by:}

Thomas A. Kufer, University of

Cologne, Germany

Reviewed by:

Janos G. Filep, University of

Montreal, Canada

Annapurna Nayak, Brunel University,

UK

*Correspondence:

Stephanie C. Eisenbarth,

Departments of Laboratory Medicine, Immunobiology and Internal

Medicine, Yale University School of Medicine, 330 Cedar Street CB403,

New Haven, CT 06520, USA

e-mail: stephanie.eisenbarth@

yale.edu
The innate immune system is composed of a diverse set of host defense molecules, physical barriers, and specialized leukocytes and is the primary form of immune defense against environmental insults. Another crucial role of innate immunity is to shape the long-lived adaptive immune response mediated by $T$ and $B$ lymphocytes. The activation of pattern recognition receptors (PRRs) from the Toll-like receptor family is now a classic example of innate immune molecules influencing adaptive immunity, resulting in effective antigen presentation to naïve T cells. More recent work suggests that the activation of another family of PRRs, the NOD-like receptors (NLRs), induces a different set of innate immune responses and accordingly, drives different aspects of adaptive immunity. Yet how this unusually diverse family of molecules (some without canonical PRR function) regulates immunity remains incompletely understood. In this review, we discuss the evidence for and against NLR activity orchestrating adaptive immune responses during infectious as well as non-infectious challenges.

Keywords: NLR, dendritic cell, NLRP3 inflammasome, NLRP10, vaccine response, autoimmunity, Th2 response, asthma

\section{INTRODUCTION}

When pathogens or injuries threaten the body, two different branches of the immune system work together to restore homeostasis: the innate and adaptive immune systems. They monitor the tissues of vertebrates and use different tactics to recognize and overcome threats. These two branches are inherently different in the sensors and mechanisms employed in order to provide either immediate protection with broad specificity (innate immunity) or delayed and prolonged protection with exquisite specificity (adaptive immunity). Further, the two branches must effectively coordinate a response in order to prevent excessive or inappropriately targeted inflammation. As Charles Janeway wrote in 1992, "the immune system evolved to discriminate infectious non-self from non-infectious self" (1). We will use this paradigm to develop a broadened classification system of five adaptive immune response types and then review how nucleotide-binding oligomerization domain-containing receptors (NOD-like receptors or NLRs) potentially regulate the response to each. These five categories are based on the origin of the target antigen affected by the adaptive immune response: (1) foreign pathogenic targets (i.e., antimicrobial immunity); (2) foreign non-pathogenic targets (i.e., allergies); (3) self targets (i.e., autoimmunity); (4) altered self targets (i.e., tumor immunity); and (5) foreign self targets (i.e., commensal homeostasis). The role of NLRs in each category is likely different, as the initiation of immunity as well as the outcome for the host are different (e.g., beneficial protection to pathogens versus loss of tolerance resulting in self-destruction).

\section{PATTERN RECOGNITION RECEPTORS IN INNATE AND ADAPTIVE IMMUNITY}

The innate immune system consists of barriers, networks of soluble mediators, and myeloid-derived executioner (effector) cells including macrophages, dendritic cells (DCs), and granulocytes.
It utilizes evolutionary conserved receptors to survey the extracellular and intracellular environment for pathogenic elements and injury. These molecules include pattern recognition receptors (PRRs) and as the name suggests, they are able to recognize a variety of common molecular motifs called "pathogen/microbe associated molecular patterns" (PAMPs/MAMPs) derived from microbes, and "damage associated molecular patterns" (DAMPs) derived from mislocalized or damaged host molecules during states of cell stress (2). PRRs exist in transmembrane, secreted, and cytosolic forms. Toll-like receptors (TLRs) are located on the cell surface and in endosomal compartments where they can recognize extracellular or phagocytosed pathogens (3). C-type lectin receptors (CLRs) can be found in both membrane-bound and secreted forms, and bind carbohydrate-based PAMPs and DAMPs (4). RIG-I-like receptors (RLRs), AIM2-like receptors (ALRs), and other nucleic acid sensing PRRs along with NLRs are located exclusively in the cytosol and nucleus, where they detect pathogens or processes that breach the cell membrane $(2,5-7)$. NLRs respond to a wide variety of PAMPs and DAMPs as well as intracellular and extracellular signals generated by other arms of the innate and adaptive immune system. Following PRR activation, various signaling cascades are induced that initiate or shape the appropriate inflammatory response and, mostly through the action of DCs, activate $\mathrm{T}$ and $\mathrm{B}$ lymphocytes of the adaptive branch of the immune system. As the highly specific antigen receptors on lymphocytes can sense an almost infinite diversity of antigens, a crucial distinction between an "appropriate" and an "inappropriate" target for the adaptive immune response is made during this step.

\section{NLR FAMILY ARCHITECTURE AND FUNCTIONS}

The array of cellular responses regulated by NLRs is striking and includes transcription (e.g., of MHC molecules), enzymatic activity (e.g., of caspases), and positive and negative regulation of 


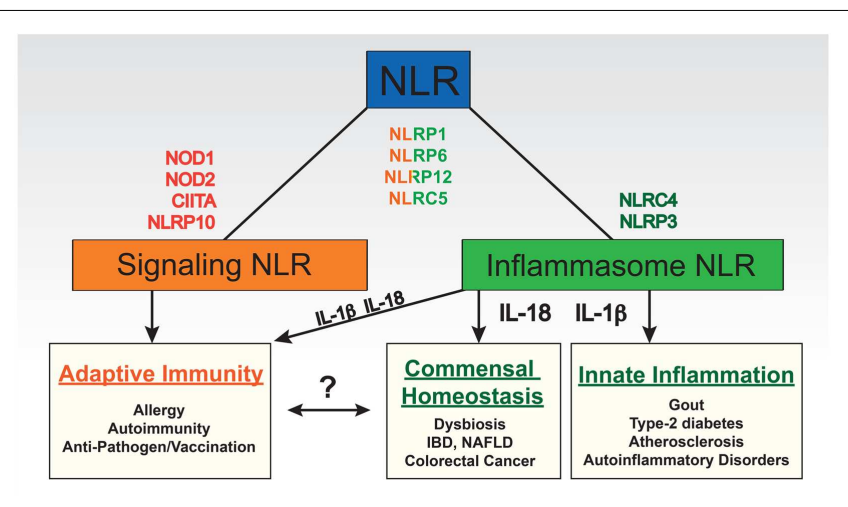

FIGURE 1 | Functional categories of NLRs based on their roles in shaping immune responses. Some NLRs have been found to play primary roles in regulating particular pathways (e.g., transcription) or signaling cascades ("signaling NLRs") such as NOD1, NOD2, NLRP10 (putative signaling NLR), and CIITA. Others regulate the formation of inflammasomes ("inflammasome NLRs") such as NLRP3 and NLRC4. Some do both such as NLRP1, NLRC5, NLRP6, and NLRP12. The immune consequences of these broad categories can be quite different. Although IL-1 $\beta$ and IL-18 derived from inflammasome activity can regulate particular aspects of adaptive immunity, direct roles of each of these cytokines in promoting non-lymphocyte based inflammatory reactions or commensal flora in the gut have also been identified. The latter has been implicated in shaping the adaptive immune system and therefore we linked these two categories; however, no direct role has yet been identified for an NLR in this link. On the other hand, NLRs involved in signaling cascades that in particular effect dendritic cell function as antigen presenting cells have a more obvious direct effect on adaptive immunity. IBD, inflammatory bowel disease; NAFLD, non-alcoholic fatty liver disease.

intracellular signaling cascades (e.g., NF-кB pathway) (Figure 1). This latter category of signaling NLRs primarily modulates pathways relevant to the innate immune response or its regulation of adaptive immunity. Signaling through NOD1 and NOD2, after sensing various bacterial peptidoglycan fragments, results in the activation of pro-inflammatory NF- $\mathrm{KB}$ and MAPK pathways, and the induction of autophagy (8-11). Extensive work on the biochemistry, ligands, and role of NOD1 and NOD2 in the innate and adaptive immune response has been done and is the topic of an accompanying review by Boyle et al. (12). NLRP10 and NLRP12 are required for the migration of antigen presenting cells (APCs) and thus have a role in defining the onset of adaptive immunity as will be discussed further in subsequent sections $(13,14)$. The NLRs CIITA and NLRC 5 are induced by cytokines and act as transcriptional activators of MHC molecules, thereby potently regulating adaptive immunity. CIITA controls the transcription of MHC class II molecules and related proteins necessary for the presentation of antigen to $\mathrm{CD} 4^{+} \mathrm{T}$ cells; NLRC5 does the same for MHC class I molecules and related proteins $(15,16)$ although it appears to have a broader function in pathogen sensing as well (17-19). In addition, several NLRs appear to have functions unrelated to the recognition of pathogens or damage, such as tissue homeostasis and embryonic development; however, further research is needed to unravel their exact roles (20).

Some NLRs perform more than one of these functions and for a majority of NLRs no known function has yet been identified.
Therefore NLRs are classified by their structure, which consists of three distinct parts: a central nucleotide-binding domain (NBD), a carboxy-terminal leucine-rich repeats (LRR), and an aminoterminal effector domain. The effector domain instigates activity and divides NLRs into four subfamilies: the NLRA family, with an acidic domain, the NLRB family, with a baculoviral inhibitory repeat (BIR) domain, the NLRC family, containing a caspase activation and recruitment domain (CARD) and the NLRP family, which has a pyrin domain. Only NLRP1 and NLRP10 do not have this basic structure $(21,22)$. The only domain common to all NLRs is the central NBD, which has ATPase activity and is thought to induce oligomerization of the NLR proteins following activation (5).

\section{NLR ACTIVATION}

The classic paradigm for the function of a pattern recognition receptor was established through the study of TLRs. TLRs sense a foreign motif (e.g., a PAMP) on a pathogen through receptor ligation of the LRR domain, resulting in the induction of an inflammatory response and enhanced antigen presentation to lymphocytes [reviewed in Ref. (6)]; however, this paradigm does not fit the NLRs. Except for a few members like NOD1, NOD2, and NAIP5 (23-27), there is limited direct evidence that the LRR actually recognizes their respective agonists (28). It has been difficult to precisely define how NLRs bind ligands, activate, and oligomerize, although from electron microscopy data, a wheel-like structure analogous to many of the other oligomerized STAND (signal transduction ATPases with numerous domains) proteins appears to form (29-31). A recent crystal structure of part of NLRC4 in the inactive state suggests that the activity of this NLR is indeed regulated by the LRR domain along with the adjacent helical domain HD2 (32). Yet it had been previously demonstrated that instead of directly interacting with its ligands, NLRC4 senses PAMPs with the help of adaptor NLRs NAIP2 and NAIP5, which associate with PrgJ and flagellin of flagellated bacteria, respectively, and control the oligomerization of NLRC4 after ligand binding $(25,33)$.

Despite the many known stimuli, including insoluble crystals, bacterial toxins, and extracellular ATP, the mechanism by which NLRP 3 is activated is only recently becoming clear. Because of the diversity of these ligands, it is likely that they activate NLRP3 through a shared mechanism involving desequestration of a host-derived trigger $(34,35)$. Sensing of increased cytosolic reactive oxygen species (ROS), intracellular calcium fluxes (36-38), potassium efflux (39-42), protein kinase (PKR) binding (43), or the release of contents from phagolysosomes have all been proposed as mechanisms. Numerous recent studies have honed in on mitochondrial-derived triggers regulating the cellular processes listed above or release of NLRP3 ligands from mitochondria including ATP, DNA, ROS, or mitochondria-associated adaptor molecule (MAVS) $(38,44-51)$. Given the importance of the mitochondria in regulating cell death, the potential triggering of NLPR3 activity by mitochondrial-derived signals suggests an interesting and central role for this organelle in integrating numerous cellular insults into a set of cell fate outcomes, some of which might be NLR-dependent (52). Biochemical identification of NLRP3 and other NLR-specific ligands, whether PAMPS, DAMPS, or more traditional signaling pathway molecules, will 
greatly facilitate our understanding of how NLRs shape both innate and adaptive immunity.

\section{INFLAMMASOME COMPLEXES}

After recognition of a PAMP or DAMP, a number of NLRs (NLRP1, NLRP3, NLRP6, NLRP7, NLRP12, NLRC4, NLRC5, NAIP2, NAIP5) form multi-protein complexes called inflammasomes $(19,33,53-56)$. The signature events of a functional inflammasome are the activation of caspase- 1 and subsequent cleavage of the pro-inflammatory cytokines IL-1 $\beta$ and IL-18 into their bioactive forms. Inflammasomes are thought to consist of multiple copies of an NLR that, after ligand sensing, recruit the protease pro-caspase-1. In most inflammasomes, these proteins are oligomerized by an adaptor protein called ASC (apoptosisassociated speck-like protein containing a CARD). ASC consists of both a pyrin domain and a CARD domain, which enable it to interact with the pyrin domain of the NLR and the CARD domain of pro-caspase-1. NLRC4 and mouse NLRP1b do not need ASC to form an inflammasome, but when ASC is recruited, the production of cytokines following NLRC4 signaling is much more efficient (57-59). However, since no NLR inflammasome structure has yet been solved $(30,60)$, there is still debate on the exact composition of inflammasomes. A "non-canonical" pathway resulting in inflammasome function has recently been described, in which caspase-11 activation by cytosolic Gram-negative bacteria such as Escherichia coli and Citrobacter rodentium enhances caspase-1 inflammasome activity or instigates cell death (61-63).

\section{HOW NLRS MIGHT SHAPE THE FIVE CATEGORIES OF ADAPTIVE IMMUNE RESPONSES DENDRITIC CELLS IN INNATE AND ADAPTIVE IMMUNITY}

The numerous pathogens we encounter everyday do not normally cause disease because most are quickly eliminated by our innate immune system. Under certain circumstances, some pathogens can evade our first line of defense and our adaptive immune system must use alternative tactics to combat the invading pathogen. APCs are critical for initiating this adaptive immune response by processing antigen and presenting it to naive T cells. Among APCs, DCs are thought to be the most potent as they temporally express requisite $\mathrm{T}$ cell co-stimulatory molecules, are readily motile and are widely distributed throughout the body forming a remarkable network of sentinel cells $(64,65)$. Under the steady state, DCs patrol the body seeking out evidence of invasion or malfunction. They express a variety of PRRs, including TLRs, NLRs, RLRs, and CLRs; PRRs are one major pathway DCs use to recognize either foreign invaders (containing PRR-stimulating PAMPs) or self molecules that have become altered (e.g., dying or transformed cells containing DAMPs). PRR activation dramatically impacts DC function by altering antigen presentation, phagocytic and macropinocytic capacity, and migratory properties. This allows DCs in peripheral tissues to transmit information about infection or tissue damage to the distal secondary lymphoid organs where naïve T-cells await stimulation.

The role of TLRs in shaping adaptive immunity via modulating DC function is well-studied, while the role of NLRs in adaptive immunity is less well understood. Recent studies suggest that the NLRs NOD1 and NOD2 might influence T cell differentiation via enhancing cytokine production from DCs in synergy with TLRs $(66,67)$. Work from our group and others demonstrated that particular NLRs can regulate DC migration during inflammation and infection $(13,14,68)$. Antigen presentation depends critically on CIITA and NLRC5 while inflammasome activation results in IL- $1 \beta$ and IL-18 production, which can have both autocrine effects on DC maturation as well as shape the differentiating $\mathrm{T}$ cell cytokine profile (Figure 2). Despite these few examples, most of the work on NLRs has not clearly elucidated how DCs are affected by NLR activity. We will discuss those studies that have addressed the role of NLRs in shaping each of the five categories of adaptive immunity defined above and highlight findings regarding DCs when known.

\section{CATEGORY 1: ADAPTIVE IMMUNITY TO FOREIGN PATHOGENIC TARGETS}

Unlike the well-studied TLRs, which detect extracellular or endosomal PAMPs, the NLRs respond to pathogens that have reached the cytosol or the accompanying cell damage caused by breaching the cell membrane. Accordingly, NLRs can respond to particular pathogens that might evade detection by TLRs or other PRRs. For those NLRs that have been studied, much of the work regarding immune consequences of NLR activity has either used in vitro systems or evaluated the acute innate immune responses in vivo. Therefore knowledge regarding how NLRs shape adaptive immunity during infection is largely incomplete. In this section we will discuss only those studies that addressed regulation of adaptive immune responses to bacterial, viral, parasite, or fungal pathogens.

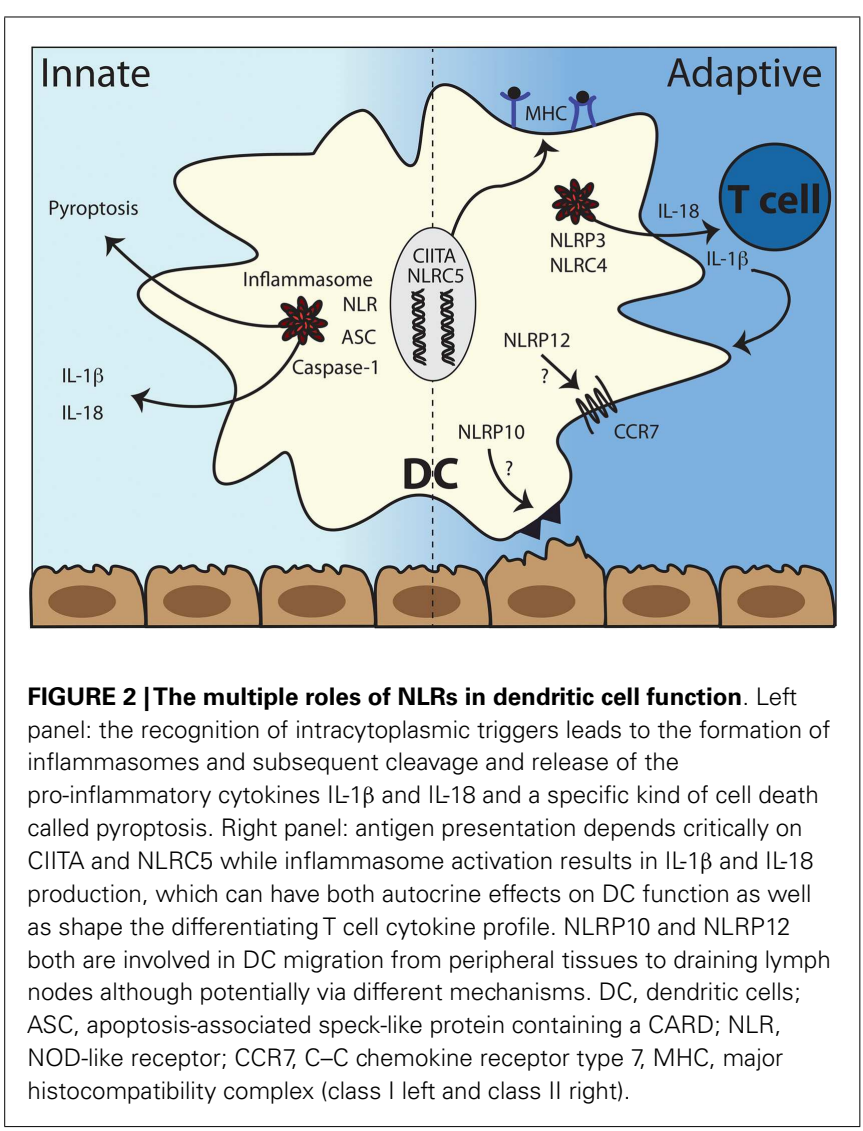




\section{BACTERIA}

Nucleotide-binding oligomerization domain-containing receptors are well suited to detect live cytosolic bacteria via PAMP recognition such as flagellar proteins or the cellular effects invading bacteria induce such as pore formation by toxins or secretion systems. The exotoxin pneumolysin (PLY) from Streptococcus pneumoniae is an important virulence factor responsible for forming pores in cell membranes (69). It was previously shown that PLY was crucial for caspase- 1 activation and subsequent IL- $1 \beta$ and IL18 production during pneumococcal infections $(70,71)$. In line with this, a recent study demonstrated that PLY activation of the NLRP3 inflammasome synergized with TLR agonists on S. pneumoniae to enhance secretion of IL- $1 \beta$, IL- $1 \alpha$, and TNF- $\alpha$ by DCs and promote IL-17A and IFN- $\gamma$ production by splenocytes $(72$, 73). Accordingly, NLRP3-deficient mice were more susceptible to pneumococcal pneumonia, suggesting that the inflammasome and its components contribute to the protective immune response to this bacterium.

A particularly crucial NLR poised to detect intracellular pathogens and orchestrate the subsequent adaptive immune response is NLRC5. Although NLRC5 has been reported to have a variety of functions in the innate immune response, its role in transcriptional regulation of MHC class I gene expression is essential for driving $\mathrm{CD}^{+} \mathrm{T}$ cell priming to intracellular bacteria such as Listeria monocytogenes (18). NLRC5 expression is enhanced by PAMP as well as IFN- $\gamma$ stimulation of hematopoietic cells and it can move from the cytosol into the nucleus where it binds and transactivates mouse and human class I genes as well as associated genes such as $\beta 2$ microglobulin and TAP1 $(74,75)$. Therefore NLRC5 has a fundamental role in antigen presentation. The role of NLRs is less clear in another intracellular bacterial infection, Mycobacterium tuberculosis (Mtb). Mtb readily infects macrophages in vitro, which subsequently secrete IL-1 $\beta$ and IL-18 in a NLRP3 inflammasome-dependent manner (76-79). As signaling through the IL-1 receptor and MyD88 are required for protection during $M t b$ infection, inflammasome regulation of protective immunity seemed likely. Using heat-killed $M t b$ as part of the potent adjuvant complete Freund's adjuvant (CFA), Shenderov and colleagues indeed demonstrated a profound impairment of Th17 differentiation in ASC- and caspase1 -deficient mice secondary to reduced IL-1 $\beta$ stimulation of $\mathrm{T}$ cells (80). Yet in vivo with a live infection, IL-1 $\beta$ levels in the lung are unaffected by loss of ASC or caspase-1 and bacterial burden and mortality in inflammasome-deficient mice are not significantly different from WT mice $(76,77,79)$. Although IL-1 $\beta$ processing and secretion are, under most circumstances, inflammasome dependent, IL- $1 \alpha$ is often secreted in an active form in an inflammasome-independent fashion (81). As both cytokines activate IL-1R1 and either cytokine alone is sufficient for protection during $M t b$ infection, it is perhaps not surprising that NLRP3 and the associated inflammasome components are dispensable for protective immunity (82).

Although numerous studies on NLRC4 have described its role in the innate immune response to flagellated bacteria, only a few investigations evaluated the role of NLRC4 in generating adaptive immunity to bacteria. Flagella from Salmonella, Yersinia, and Pseudomonas activate the NLRC4 inflammasome in splenic
CD8 $\alpha^{+}$DCs to release IL- $1 \beta$ and IL-18; IL-18 can stimulate IFN- $\gamma$ production from non-cognate memory $\mathrm{CD}^{+} \mathrm{T}$ cells in the spleen thereby enhancing host resistance to bacterial infection (83). Caspase- 1 regulated IL- $1 \beta$ and IL- 18 production from DCs was also crucial for both Th1 and Th17-dependent protective immunity during Helicobacter pylori infection or even following vaccination, although the relevant NLR involved remains unknown (84). Caspase-1-, ASC-, and IL-18-deficient mice are all more susceptible to infection with the intracellular bacterium Anaplasma phagocytophilum as a result of inadequate Th1 activity. Partially via the inflammasome-forming activity of NLRC4, enhanced IL-18 secretion (presumably by APCs in the spleen) promotes Th1 differentiation and IFN- $\gamma$ production - a crucial cytokine in regulating A. phagocytophilum bacterial loads (85). In fact one evasion mechanism used by the pathogen Salmonella is to downregulate NLRC4 expression to prevent the inflammasome response and thereby promote bacterial persistence and dissemination (86). Therefore NLRC4 and its adaptors are well poised to detect intracellular bacteria and mount an important inflammasome-dependent IL-18 driven adaptive immune response.

\section{VIRUSES}

Toll-like receptor- and RIG-I-like receptor-mediated recognition of viral infections results in the production of a number of viral resistance pathways and in particular the secretion of type I IFNs; in contrast, NLRs do not directly regulate IFN $\alpha$ or IFN $\beta$ and in fact inflammasome-driven pathways can be inhibited by these cytokines. Most NLRs do not directly recognize viral motifs but rather respond to cell disruption induced during viral infection with inflammasome-dependent cytokine secretion (87-89). The most extensively studied virus that activates inflammasome pathways is the respiratory pathogen influenza. Much like the pore forming bacteria described above, influenza can activate the NLRP3 inflammasome via insertion of a proton-selective ion channel, which it uses to change ionic gradients in intracellular compartments during viral entry and propagation, but also alerts NLRP3 to presence of the virus (90).

It is well known that IL-1 cytokines are crucial to the Th1 and $\mathrm{CD}^{+} \mathrm{T}$ cell adaptive immune response to influenza; accordingly, ASC and caspase- 1 are also needed for protective adaptive immunity $(91,92)$. A recent paper showed that DCs from elderly mice exhibited decreased expression of ASC, NLRP3, and caspase-1 compared with DCs from infected young mice and the concomitant blunted IL- $1 \beta$ response resulted in enhanced morbidity and mortality in influenza-infected elderly mice (93). A similar study demonstrated that TLR3 or NLRP3 stimulating adjuvants enhanced the efficacy of influenza virus-like particle vaccines in aged mice (94). These studies suggest that suppressed NLRP3 inflammasome activity during aging impairs protective adaptive immunity to influenza. Yet the course of influenza infection in different studies using NLRP3-deficient mice widely varied with some studies showing enhanced influenza susceptibility and others showing no difference $(92,95,96)$. It was suggested that these opposing results might be due to different doses of influenza virus inoculation or the different viral strains used in these studies (92), but an alternative explanation might come from recent data on the role of IL-1 cytokines in regulating DC migration 
during influenza infection. Pang et al. found that IL-1 signaling in pulmonary DCs was required for proper DC migration to lung draining lymph nodes and subsequent activation of influenza specific T cells; however, DC intrinsic activation of NLRP3 was not needed for antigen presentation or T cell priming (97). Therefore, much like the pathways described for $M t b$, if inflammasomeindependent IL-1 $\alpha$ can be generated during infection, adaptive immunity should be minimally impacted in the absence of NLRP3, ASC, or caspase-1.

West Nile virus (WNV) is an emerging flavivirus capable of infecting the central nervous system (CNS) and mediating neuronal cell death. A recent study demonstrated that acute WNV infection induced IL-1 $\beta$ production in vivo, and that IL-1-R-, caspase-1-, and NLRP3-deficient mice exhibited increased susceptibility to WNV (98). This outcome was associated with increased accumulation of virus within the CNS and reduced anti-viral activity of effector $\mathrm{CD}^{+} \mathrm{T}$ cells. This study indicates that IL$1 \beta$ signaling and the NLRP3 inflammasome are important for host control of virus replication in neurons and WNV-induced pathology in the CNS.

\section{PARASITES}

Although the NLRP3 inflammasome is activated during many parasitic infections (e.g., Leishmania major) or by byproducts of parasitic infections (e.g., malarial hemozoin) and its effect on the acute innate immune response is well documented, the role of NLRP3 or other NLRs in the adaptive immune response to parasites has not been extensively studied $(99,100)$. The role of the NLRP3 inflammasome in shaping the T cell response to Schistosoma mansoni has been studied (101); the authors found that both ASC- and NLRP3-deficient mice failed to upregulate IL-1 $\beta$ in the liver and all parasite-specific helper T cell responses (Th1, Th2, and Th17) were reduced after infection compared to wild type controls. Surprisingly, these impaired T cell responses were correlated with smaller liver granulomas and attenuated immunopathology in the inflammasome-deficient mice, suggesting enhanced adaptive immunity to Schistosoma by NLR activation is not necessarily beneficial to the host.

\section{FUNGI}

It has been reported that Candida albicans hyphae activate NLRP3 $(102,103)$ and NLRP3-deficient mice succumb to both disseminated Candidiasis (102, 104) and mucosal Candidiasis (103), suggesting that the inflammasome is crucial for anti-fungal host defense. Caspase-1- and ASC-deficient mice indeed have impaired Th1 and Th17 responses during Candida albicans, leading to increased fungal outgrowth and reduced survival (105). Further, exogenous IL-18 was able to restore Th1 immunity to Candida in caspase-1-deficient mice (106), indicating that inflammasomederived cytokines direct protective adaptive immune responses during invasive fungal infection.

NLRP10 has a critical role in DC localization in vivo; in its absence, impaired DC migration results in a profound helper $\mathrm{T}$ cell priming defect in a number of immunization models (14). In line with this, NLRP10-deficient mice have increased susceptibility to disseminated Candidiasis, as indicated by decreased survival and increased fungal burdens, secondary to impaired induction of Candida-specific Th1 and Th17 responses (68). In fact, adoptive transfer of Candida-specific primed T cells from WT mice rescues NLRP10-deficient mice infected with Candida. Therefore NLRP10, by regulating the movement of DCs presumably in the spleen in this case, can dramatically regulate pathogen-specific adaptive immunity. It still remains to be determined how NLRP10 activity is triggered during Candida infection and the molecular function of NLRP10 that regulates DC migration.

\section{CLINICALLY APPROVED VACCINE ADJUVANTS}

The development of vaccines against infectious pathogens has been and continues to be one of the most important medical interventions in global health. Many of our current vaccines do not induce adequate immunity unless co-administered with an adjuvant, which helps initiate adaptive immunity by stimulating the innate immune system. Although many pathogenderived adjuvants used in animal models (e.g., CFA containing heat-killed mycobacteria or immunostimulatory oligodeoxynucleotides containing CpG motifs) have the capacity to stimulate various TLRs and NLRs, almost all clinically approved adjuvants for human use in fact do not contain any pathogen-derived motifs. Instead the most commonly employed adjuvants in human vaccines are aluminum hydroxide, which is a crystalline mixture and MF59, which is an oil-in-water emulsion. We and a number of other groups hypothesized that these adjuvants might trigger a DAMP-dependent rather than PAMP-dependent innate immune response thereby accounting for their immunostimulatory properties. Indeed alum is a potent activator, like many other insoluble crystals, of the NLRP3 inflammasome (107-111); however, whether triggering this innate immune pathway subsequently instructs the adaptive immune response during vaccination remains unclear (112). Different groups using the same mice with similar models have observed opposing phenotypes, possibly suggesting that multiple factors influence whether NLRP3 is relevant to the adjuvant function of alum. Some studies, including our own, have suggested that induction of adaptive immunity following alum-based vaccination requires a functional NRLP3 inflammasome via maturation of DCs $(107,109,110)$; however, other groups found that NLRP3-deficient mice had intact $\mathrm{T}$ and $B$ cell responses following vaccination with alum and antigen $(108,111,113)$. Further, numerous other pathways downstream of alum immunization have now been proposed to be required for its adjuvant function, including DNA released during cell death, lysosomal permeabilization resulting in cathepsin B and S release, extracellular ATP, and uric acid release (114-117). Surprisingly, all of the above stimuli have also been directly implicated in NLRP3 inflammasome activation, yet in all cases NLRP3 was not required for successful immunization, leaving us without consensus on the mechanism by which alum regulates adaptive immunity. As alum has proven to be a great adjuvant for almost 100 years in that it works in most people, it is likely that it has multiple routes to induce immunity. In isolated systems used by different groups using murine models we have uncovered some, but perhaps not all, of those mechanisms.

A similar story has emerged for the oil-in-water adjuvant MF59 $(118,119)$. Ellebedy et al. showed that although NLRP3 is dispensable for the adjuvant effect of MF59, ASC is crucial for 
the induction of antigen-specific IgG following vaccination with H5N1 in combination with MF59 (118). Indeed, activation of both germinal center $\mathrm{B}$ cells and $\mathrm{CD} 4^{+} \mathrm{T}$ cells are significantly reduced in ASC-deficient mice, but not in NLRP3- or caspase-1-deficient mice. As it has been shown that DCs take up both antigen and MF59 and transport them to draining lymph nodes $(120,121)$, the markedly reduced secretion of inflammatory cytokines by ASCdeficient DCs upon stimulation with MF59 may be responsible for impaired $\mathrm{T}$ and $\mathrm{B}$ cell responses (118). Consistent with these findings, Seubert et al. also demonstrated that NLRP3 is not required for induction of adaptive immune responses to Neisseria meningitides with three particulate adjuvants: alum, MF59, and CFA (119).

Apart from traditional adjuvants, nanoparticles have been extensively studied as vehicles to co-deliver antigens and adjuvants for effective vaccination (122). Using a biocompatible polyester, poly(lactic-co-glycolic acid) (PLGA), loaded with antigen Demento et al. demonstrated that LPS-modified particles are preferentially internalized by DCs compared to uncoated nanoparticles and elicit NLRP3 inflammasome activity (123). Further, inhibition of endocytosis and lysosomal destabilization diminished inflammasome activity, suggesting that the rupture of lysosomal compartments by nanoparticles is a crucial trigger for inflammasome activation $(123,124)$. A more recent study found that porous silicon nanoparticles enhance phagocytosis and subsequent activation of DCs as well as IL- $1 \beta$ production (125). Administration of these nanoparticles also enhances DC migration to draining lymph nodes and $\mathrm{T}$ cell priming. However, adaptive immunity was either not evaluated in these studies or only partially affected in the absence of NLRP3, again leaving us with a vaccine formulation that can activate the inflammasome but might not absolutely require its activity for the initiation of adaptive immunity.

Nucleotide-binding oligomerization domain-containing receptors not only perform a major role in innate immune responses, but also have defined roles in generating effective adaptive immune responses against various infections. However, a number of important questions remain unanswered, including the mechanism by which NLRs detect molecules of microbial origin as well as how NLRs cooperate with other PRRs to mount an effective immune response against pathogens. It is possible that some NLRs serve as direct receptors of PAMPs, while others instead detect the perturbation of the host microenvironment by pathogens (42). Undoubtedly, understanding how NLRs recognize microbial products and initiate subsequent adaptive immune responses will provide new insights into vaccine design and vaccination strategies against infectious diseases.

\section{CATEGORY 2: ADAPTIVE IMIMUNITY TO FOREIGN NON-PATHOGENIC TARGETS}

The diversity of molecules that can act as allergens is immense with the only unifying theme being the allergic type 2 immune response induced; in most cases this immune response is driven by Th2 lymphocytes [for review, see (126)]. Allergens are foreign, non-self molecules, and as such could trigger innate immune responses. Yet as most [but not all (126)] of these molecules are considered inherently non-pathogenic, it is unclear if they trigger classic PRR pathways. Many allergens indeed have enzymatic activity or are pathogen-derived (e.g., helminths) or can mimic
PAMPs (e.g., Derp 2) and this might be how the innate immune system is tricked into initiating adaptive immunity $(127,128)$. Are NLRs involved in sensing allergens as pathogenic and determining the subsequent maladaptive immune response? Given that some allergens can directly induce tissue damage along with previous implications of IL-1 and IL-33 in Th2-mediated inflammatory responses, the prediction that NLRs play a role in the development of allergic diseases seems obvious. However, the evidence in favor of this argument is limited (129).

IL-33 is a prime candidate in the development of allergy as it clearly promotes Th2 (as well as ILC2) responses (130-133). Early work in the inflammasome field suggested that IL-33 was cleaved by caspase- 1 and so this cytokine was grouped with the other inflammasome-regulated cytokines IL-1 $\beta$ and IL-18 and further postulated to be one mechanism by which inflammasome activity could regulate Th2 development (107). However, more recent work indicates that active IL-33 is in fact released from necrotic cells and functions more like a DAMP; if IL-33 is instead cleaved by caspase- 1 or by caspase- 3 during apoptosis it becomes inactive and fails to bind its receptor T1/ST2 (134-136). Therefore, the data supporting a role for IL-33 in the development of Th2-driven allergic inflammation indicates that this cytokine can function like a DAMP and shape the immune response but does not implicate a role for inflammasome activity in such a process.

\section{LUNG}

Similar to the diversity of antigens that can serve as allergens, there is a spectrum in the pathophysiology of the major allergic lung disease, asthma. The classic form is triggered by inhaled allergens that trigger degranulation of mast cells and basophils in the lung in an IgE-dependent manner and results in airway constriction and mucus production along with tissue inflammation dominated by activated eosinophils. Although the IL-1 gene cluster on chromosome 2 and promoter polymorphisms in IL-18 have been weakly associated with susceptibility to asthma (137, 138), the mechanistic link between IL-1, inflammasome activity and Th2 induction is uncertain partly due to the range of allergic airway disease models employed. As many murine allergy models involve intraperitoneal administration of antigen with the potent adjuvant aluminum hydroxide, the role of NLRs during the T cell sensitization phase to allergens in lung draining lymph nodes is difficult to determine (139); indeed intraperitoneal injection models have demonstrated a range of effects in IL-1- or IL-1 receptordeficient or inflammasome-deficient mice $(113,140,141)$. In contrast, when inhalational allergens are administered with nitrogen dioxide, urban particulate matter, or with presumed low-level PAMP contamination, a more significant role for IL-1 pathways and inflammasome molecules has been observed in some (142$145)$ but not all allergic airway disease models $(113,141)$. One caveat to these latter systems however, is that they can have a significant Th17-driven inflammatory response and as some studies have demonstrated a significant role for inflammasome-derived IL- $1 \beta$ on Th17 but not Th2 induction, the observed differences in inflammation might be due to loss of the Th17 component (143, 146). Nevertheless, inflammasome activity likely via IL-1 secretion appears to modulate particular aspects of adaptive immunity to inhaled triggers. 


\section{GASTROINTESTINAL}

The disease corollary of this type of allergic adaptive immune response in the gastrointestinal system is food allergies. Outside of one study on subjects with a specific clinical subset of food allergies demonstrating an association with Nlrp3 polymorphisms (147), there has been no link yet established between NLRs and the development of adaptive immunity to food antigens.

\section{SKIN}

The other primary organ affected by allergic adaptive immunity is the skin. Disorders such as atopic dermatitis (in some cases referred to as eczema) and allergic contact dermatitis (included under contact hypersensitivity) are manifestations of an often Th1/Th2 mixed adaptive immune response to unclear targets, but can include prototypical allergens such as house dust mite antigens or small molecule contact allergens. Accordingly, the inflammasome-dependent cytokines IL-1 $\beta$ and IL-18 have been implicated in promoting aspects of both a Th2 (elevated IgE, mast cell, and basophil degranulation with overproduction of type 2 cytokines) and a Th2- and IgE-independent innate inflammatory response (basophil and mast cell degranulation) (148, 149). IL-18, traditionally thought of as a Th1-promoting cytokine, has been implicated in the development of atopic dermatitis; transgenic mice expressing either human caspase-1 or IL-18 in keratinocytes develop spontaneous atopic dermatitis-like lesions with elevated mast cell activity (148). House dust mite cysteine proteases can directly activate the NLRP3 inflammasome in keratinocytes, which has been one proposed mechanism for induction of caspase1 activity (150); however, mast cell chymase can also directly cleave pro-IL-18 independently of caspase-1 (151). Further work is needed to clarify if particular NLRs are indeed needed to direct the adaptive immune response to skin antigens in atopic dermatitis, but clearly pathways downstream of particular NLRs appear relevant.

Contact hypersensitivity is triggered by contact allergens (haptens, most often small lipophilic molecules that bind to self proteins) that induce a Th1/CD $8+\mathrm{T}$ cell driven neutrophilic inflammation. An important role for IL-1 $\beta$ in the development of contact hypersensitivity has been known for many years (152) and a role for inflammasome-forming NLRs seems likely, especially given the expression of many NLRs and associated inflammasome components in the skin (153). Multiple studies have suggested that IL-1 $\beta$ directly enhances Langerhans cell activity in priming T cells to contact allergens $(154,155)$. However, subsequent work on this unique cell has indicated that it is primarily derived from embryonic fetal liver monocytes and locally maintained in contrast with classical DCs; further, Langerhans cells migrate significantly slower (e.g., on the order of 3-4 days) to draining LNs than typical DCs $(156,157)$. Recent studies instead suggested a regulatory role of Langerhans cells to skin-derived antigens (157). Therefore, the exact role of Langerhans cells in initiating adaptive immunity to contact sensitizers is not clear. Yet separate studies using caspase1, ASC, or NLRP3-deficient mice all support a requirement for inflammasome activity in the generation of immunity to skin sensitizers $(153,155,158,159)$. This implies that inflammasomeregulated IL-1 $\beta$ might target cells other than Langerhans cells during sensitization in the skin such as dermal DCs; alternatively, inflammasome-dependent signals beyond IL-1 $\beta$ might directly modulate the lymphocyte response to contact sensitizers.

Beyond regulating inflammasome-induced cytokine secretion, NLRs can play a more direct role in regulating sensitization of $\mathrm{T}$ cells via affecting DC maturity and migration. Recently two NLRs were described to regulate the movement of DCs in an inflammasome-independent manner and gene knockouts of each had dramatic but specialized effects on allergic models in vivo. Arthur et al. demonstrated that hapten-induced contact hypersensitivity was defective in the absence of inflammasome-forming NLRP12 potentially via regulation of DC and neutrophil motility but independent of inflammasome activity (13). However, subsequent work from the same group indicated that NLRP12-deficient mice had no defect in $\mathrm{T}$ cell sensitization to antigens inhaled or administered intraperitoneally in two different allergic airway disease models (141), suggesting that NLRP12-dependent DC migration might be specific to skin DCs. NLRP10 was described by a number of groups including our own to regulate DC-dependent $\mathrm{T}$ cell priming as well as NOD1 signaling and inflammasome activity [please see (160) for review]. Our work suggests that sensitization to inhaled or subcutaneous antigens is defective in the absence of NLRP10 secondary to a DC migration defect; however $\mathrm{T}$ cell priming following topical sensitization was not evaluated (14). Therefore whether the NLRP10 and NLRP12 phenotype are complementary versus overlapping has yet to be determined. But interestingly both NLRP10 and NLRP12 were identified as susceptibility loci from GWAS studies of patients with atopic dermatitis $(161,162)$. NLRP10 is most highly expressed in the skin and knockdown of human NLRP10 in primary dermal fibroblasts attenuates innate immunity mediated by NOD1 (163). Therefore, further work is necessary to clarify if NLRP10 regulates adaptive immunity to skin antigens via hematopoietic cellular changes or rather acts in the barrier function of the skin.

\section{CATEGORY 3: ADAPTIVE IMMUNITY TO SELF TARGETS}

Autoimmunity is a pathologic process wherein T and B lymphocytes are activated by self molecules and induce damage to host tissues. As tolerance is built into the education of T and B cells, an active process must overcome tolerance to induce lymphocyte sensitization to self molecules; the innate immune system plays one key role in that process. Much of the early work on NLRs and inflammasomes followed the discovery that constitutively active mutants of NLRP3 were responsible for a subset of periodic fever syndromes now grouped under the term autoinflammatory diseases [for review, see (164)]. This NLRP3-dependent collection of rare syndromes, called the Cryopyrin-associated periodic syndromes (CAPS), is characterized by self-limited bouts of inflammation of the joints and skin with more systemic inflammation depending on the subtype; all are accompanied by fever and elevated levels of IL-1 $\beta$ (165). In fact, these disorders are now successfully treated by blocking IL- $1 \beta$ activity (166). It is important to recognize that these disorders do not include self-reactive $\mathrm{T}$ or B cells and therefore are distinct from autoimmune diseases (167). Although both autoinflammatory and autoimmune diseases involve recurrent episodes of inflammation (sometime with similar cytokine profiles) triggered by self molecules, the cells that drive inflammation and the nature by which they do so in the 
two disease categories are different. Therefore for the remainder of this section, we will only consider the role of NLRs in the adaptive immune response to self targets and therefore autoimmune diseases. In contrast to the clear mechanistic link between autoinflammatory diseases and NLR activity, the link between autoimmunity and NLR activity is more tenuous (168).

How would NLR activity drive autoimmunity? One obvious link between inflammasome-forming NLRs and adaptive immunity is the potent cytokine IL- $1 \beta$. IL- $1 \beta$ enhances expansion and survival of $\mathrm{T}$ cells (169), promotes differentiation of potentially pathogenic Th17 cells $(170,171)$ and can promote APC migration, thereby potentially enhancing antigen presentation (97) (Figure 2). Yet IL-1 $\beta$ cannot be sufficient for driving autoimmunity as autoreactive $\mathrm{T}$ and $\mathrm{B}$ cells are not a part of the pathophysiology of autoinflammatory diseases $(165,167)$. Indeed there is only limited evidence that NLR triggering induces a complete DC maturation program the way TLR activation transforms naïve DCs into potent APCs. Yet as discussed previously, particular NLRs such as CIITA, NLRC5, NLRP10, and NLRP12 regulate key steps in the antigen presenting function of DCs (34) and might regulate adaptive immunity to self in this way.

\section{MULTIPLE SCLEROSIS}

Perhaps the strongest link between an inflammasome-forming NLR and an autoimmune process is the link between NLRP3 and multiple sclerosis (MS). MS is a Th1 and Th17-driven response directed against myelin-producing oligodendrocytes in the CNS (172). Overexpression of IL-1 $\beta$, IL-18, and caspase- 1 has long been recognized in samples from MS patients (173-175). Studies in animal models further strengthened a connection between inflammasome activity and MS. A murine model with a clinical phenotype similar to MS, experimental autoimmune encephalomyelitis (EAE) exists. However this model relies on a highly artificial induction step to induce CNS-reactive T cell priming using CFA administered with peptides from the CNS (14). As Mycobacterium can activate multiple NLRs including NOD1, NOD2, and NLRP3 $(66,80,176)$, one might expect to observe differences in adaptive immune-mediated disease when the adjuvant contains Mycobacterium as does CFA. Despite bypassing the natural immunization process, this animal model has been useful to dissect the immune pathways governing the autoimmune destruction of the CNS. Indeed caspase-1-deficient mice have reduced disease severity and delayed onset of paralysis (177). Further, caspase-1 dependent IL$1 \beta$ and IL-18 from activated DCs promotes Th17 and $\gamma \delta$ T-cell activation directed against the CNS $(178,179)$.

Once the link between caspase-1 and NLRP3 was identified, an obvious question was whether this particular NLR regulates the adaptive immune response to the CNS. Yet the answer remains ambiguous. One group using two different models of EAE found that NLRP3-deficient mice had normal $\mathrm{CD} 4^{+} \mathrm{T}$ cell activation to CNS antigens but poor Th17 and Th1 differentiation. This was accompanied by reduced adaptive immune cell infiltration of the CNS and improved clinical outcomes (180, 181). Consistent with this finding, another group subsequently reported that NLRP3-sufficient DCs were required in order to program the primed autoreactive $\mathrm{CD}^{+}{ }^{+} \mathrm{T}$ cells to traffic into the CNS (182). In contrast to the above work, a third group demonstrated, using a similar EAE model that NLRP3 deficiency did not affect the development of paralysis and presumably retained autoreactive $\mathrm{T}$ cell activity (183). Instead this latter study proposed an inflammasome-independent role for the adaptor ASC in the autoimmune disease process; however, subsequent work from this group demonstrated a second mutation in their strain of ASCdeficient mice in the guanine nucleotide-exchange factor Dock2, which regulates actin polymerization during lymphocyte migration and DC antigen uptake (184). Therefore, the findings from the 2010 paper might be affected by a non-inflammasome related mutation in the ASC-deficient mice used. Nevertheless, the findings in NLRP3-deficient mice should have been unaffected and therefore still suggest NLRP3-independent induction of adaptive immunity in EAE. To date, no clear mechanism explains the discrepancy in results between groups using NLRP3-deficient mice; however, a recent paper by Inoue et al. suggests that the dose of Mycobacterium used in the CFA adjuvant determines whether a NLRP3-dependent or -independent response is observed in EAE models (185). Since, in all of the papers discussed above the dose of Mycobacterium used was not specified, it remains unclear if a difference in mycobacterial doses explains the above discrepancy. Therefore the question remains whether an inflammasomedependent step is required to initiate adaptive immunity to CNS self antigens.

We recently described another NLR crucial in the early stages of $\mathrm{T}$ cell priming against self-molecules in the CNS in a noninflammasome-dependent manner. NLRP10 regulates the movement of antigen-laden DCs and in a standard EAE model, NLRP10 deficiency almost completely abrogated the priming of IL-17 and IFN- $\gamma$ producing CD4 ${ }^{+} \mathrm{T}$ cells to $\mathrm{CNS}$ peptides and the associated demyelination (14). In this case, IL- $1 \beta$ and IL-18 production were not altered but rather autoreactive $\mathrm{T}$ cells were not activated because the crucial step of antigen presentation in secondary lymphoid organs failed. Again, given the use of CFA in this model, one can only conclude that DC movement and T cell priming are NLRP10-dependent in MS if the immune system is triggered in an analogous way during the natural course of disease.

\section{DIABETES}

In contrast to MS/EAE, no other autoimmune disease has been as clearly linked to the activity of an NLR. Type 1 diabetes (T1D) is driven by $\mathrm{T}$ cells specific for beta cells in the pancreas ultimately resulting in destruction of the islets and is accompanied by systemic production of islet-specific antibodies. Although there is mounting evidence that NLRP3 inflammasome activity promotes insulin resistance in models of type 2 diabetes (T2D) (186-188), there is scarce evidence indicating that the same is true for autoimmune T1D. In fact, the unaltered development of spontaneous diabetes in NOD mice lacking caspase-1 argues against a role for inflammasome activity in the pathogenesis of autoimmune diabetes (189). Yet various human studies have suggested that particular polymorphisms in NLRP1 and NLRP3 confer risk for T1D $(190,191)$. Further, IL-1 $\beta$ is known to promote beta cell secretory dysfunction and apoptosis and this has prompted clinical trials of IL-1 blockade in both T1D and T2D. Unfortunately though, this approach was shown to be ineffective in new onset type 1 diabetics in a recent multicenter randomized 
double-blind placebo-controlled trial (192). Older work using the mouse NOD model suggested that IL-1R blockade in fact does not alter insulitis or the autoimmune process, although glycemic control was improved (193). Therefore, inflammasome activity and IL-1 $\beta$ in particular might play a more significant role in insulin sensitivity and beta cell dysfunction (T2D) rather than regulating autoimmunity to beta cells (T1D).

\section{RHEUMATOID ARTHRITIS}

The pathology in rheumatoid arthritis (RA) is driven by a Tcell-mediated immune response directed at the synovial lining of the joints and is accompanied by autoreactive antibodies systemically. Unlike some of the other autoimmune diseases discussed above, IL-1 $\beta$ plays a less significant role in the pathology of RA (194) and therefore the role of NLRs and inflammasomes in driving the autoimmune process has been less extensively studied. A handful of studies specifically looking for polymorphisms in NLRs or associated inflammasome components has indeed found some associations with NLRP1 and NLRP3 polymorphisms and RA susceptibility $(195,196)$. Yet two groups using two different mouse models of antigen-induced arthritis reported that the adaptive immune response directed at the joints was NLRP3, NLRC4, and caspase- 1 independent $(197,198)$. Interestingly, both reported dependence instead on the inflammasome adaptor ASC. But as described above, one of these groups subsequently discovered an unintended mutation in a non-inflammasome pathway in the ASC-deficient mice relevant for antigen presentation by DCs and $\mathrm{T}$ cell activation (184). Given that both groups observed $\mathrm{T}$ cell and DC intrinsic defects in their strain of ASC-deficient mice, it is again possible that the above finding stems from an ASCindependent defect. Yet other data from these papers suggests that NLRP3, NLRC4, and caspase-1 do not appear to play a significant role in the adaptive immune response in RA models.

\section{LUPUS}

Systemic lupus erythematous (SLE or lupus) affects a wide range of organs primarily driven by immune complexes of nuclear antigens bound by autoantibodies, which initiate inflammation and tissue destruction. The primary nuclear antigen, double stranded DNA (dsDNA) can potentially act as a DAMP to trigger many PRRs including TLR7 and TLR9 (199), NLRP3 (200), and AIM2 (201) and each of these receptors has been implicated in the pathogenesis of lupus. In the case of the latter two PRRs, inflammasome function has been suggested from older studies demonstrating a crucial role for IL-1 $\beta$ (but not IL- $1 \alpha$ ) in the development of anti-nuclear antibodies and lupus disease manifestations (202). Indeed a recent elegant study by Shin et al. identified how NLRP3 is triggered by dsDNA; human monocytes produce IL- $1 \beta$ only when stimulated with dsDNA in combination with anti-dsDNA antibodies, the complexes known to trigger inflammation in lupus (200). Further, supernatants from these stimulated monocytes promoted IL-17 production from memory $\mathrm{CD} 4^{+} \mathrm{T}$ cells. This suggests that the complexes formed in lupus patients can activate myeloid cells via NLRP3 and thereby reinforce $\mathrm{T}$ cell activation. It remains unclear though if this process and the NLRP3 inflammasome are required for initiation of the self-directed adaptive immune process. In fact a recent limited genetic analysis of $N l r p 3$ (and Aim2) failed to find an association of particular single nucleotide polymorphisms (SNPs) with SLE predisposition; instead, polymorphisms in Nlrp1, including one in the promoter region, were associated with SLE in a Brazilian population (203).

Interestingly, non-synonymous coding-region and promoter polymorphisms in Nlrp1 have been recurrently identified in genetic screens for a number of autoimmune diseases including vitiligo (melanocytes in the skin and hair targeted), Addison's disease (cortex of the adrenal gland targeted), type 1 diabetes (beta cells in the pancreas targeted), systemic sclerosis (nuclear antigens targeted), RA (synovium in joints targeted), and SLE (nuclear antigens targeted) $(190,191,195,203-206)$. Frustratingly, there has been little work done to identify how these various polymorphisms influence autoimmunity susceptibility outside of a possible effect on transcription level of Nlrp1 (195). Indeed little is known about the function of NLRP1 in vivo, in part due to the divergence of Nlrp1 genes between humans and mice. But of all NLRs discussed, NLRP1 is the most widely implicated in susceptibility to autoimmunity in human studies. Until a mechanistic understanding of these SNPs is discovered, the association with autoimmunity does not provide a paradigm in which to develop a role for NLRP1 in the initiation of adaptive immune processes directed against self molecules.

\section{CATEGORY 4: ADAPTIVE IMMUNITY TO ALTERED SELF TARGETS}

As tumors are derived from host cells that have lost the ability to regulate their appropriate growth, there is little to mark them as foreign or dangerous to the immune system. Outside of the aberrant loss of particular inhibitory signals to immune cells or altered forms of a self molecule, one signal that might alert the innate immune system to the loss of homeostasis is excessive cell turnover and damage to surrounding tissue, leading to the release of DAMPs. Therefore NLRs might be a relevant pathway to detect unchecked proliferation in tumors and initiate an immune response to these altered host-derived cells. However, several studies have suggested that IL- $1 \beta$ may have a role instead in promoting tumorigenesis $(207,208)$, since reducing or eliminating IL- $1 \beta$ can prevent tumor metastases and progression $(209,210)$, thus suggesting that inflammasome signaling may play a more complex role in the tumor-immune system interaction.

\section{COLON}

Most studies of NLR function in tumorigenesis have focused on colonic inflammation and tumor models. NLRs are involved in the maintenance of gut homeostasis and dysregulation of this fine-tuned balance can lead to chronic inflammation (please see Category 5: Adaptive Immunity to Foreign Self Targets), which is believed to create a tumor-promoting condition for intestinal cancer. Accordingly, mice deficient in caspase-1, ASC, NLRP3, NLRP6, NLRP12, and NLRC4 all have increased colitis and subsequent development of colorectal cancers in gut irritant models. In most of these studies caspase- 1 processed IL-18 is a key regulator of these processes (211-214). Although most of these chronic models did not evaluate potential alterations in anti-tumor adaptive 
immunity, one study showed that in the absence of NLRP3 and caspase-1, reduced IL-18 in a colorectal tumor model led to diminished IFN- $\gamma$ levels in the colon (214). However, the cellular origin of this IFN- $\gamma$ was not identified and therefore it remains unclear if anti-tumor adaptive immunity was in fact altered. In contrast, IL-18 has been implicated in promoting tumor metastasis from the lung, but in a T-cell and B-cell independent fashion; tumorderived IL-18 promoted increased expression of the inhibitory receptor PD-1 on NK cells and prevented effective immunosurveillance (215). Therefore there might be a very different effect of inflammasome activity outside of the gut, wherein secreted IL-1 $\beta$ and IL-18 actually suppress tumor surveillance by innate cells but perhaps ultimately promote adaptive immunity to tumor antigens.

\section{TUMOR VACCINES}

Chemotherapy is one of the most commonly used treatments for cancer patients. It has been proposed that chemotherapy works via eliminating immunosuppressive cells and by directly inducing tumor-cell death $(216,217)$. Ghiringhelli et al. demonstrated that chemotherapy-treated dying tumor cells can activate the NLRP3 inflammasome in DCs and that a functional NLRP3 inflammasome in DCs is required for tumor-specific CD8+ T cell priming (217). In this study, the authors found that NLRP3- and caspase-1deficient mice are unable to prime $\mathrm{CD}^{+} \mathrm{T}$ cells, unless exogenous IL- $1 \beta$ is provided. Furthermore, they found that HMGB1 from dying tumor cells is critical for IL- $1 \beta$ release by DCs. In contrast, van Deventer et al. found that NLRP3 activity actually impairs anti-tumor DC-based vaccination by enhancing the accumulation of tumor-associated myeloid-derived suppressor cells (MDSC) thereby inhibiting the cytotoxic T cell response (218). Tu et al. also found enhanced MDSCs in gastric tumors induced by overexpression of IL-1 $\beta$ in the stomach; however, the enhanced tumor development was independent of $\mathrm{T}$ and $\mathrm{B}$ lymphocyte responses (219). In line with these studies, Bruchard et al. demonstrated that although chemotherapy depleted MDSCs and increased the survival of tumor-bearing mice by generating tumor-specific $\mathrm{CD}^{+}$ $T$ cells, it triggered the release of cathepsin B from MDSCs leading to IL-1 $\beta$ secretion (220). IL- $1 \beta$ promoted IL-17 production from $\mathrm{CD}^{+}{ }^{+} \mathrm{T}$ cells, which in turn attenuated the anti-tumor effect of chemotherapy via an IL-17-dependent proangiogenic effect (220). These conflicting results may be due to the ability of particular drugs to induce immunogenic tumor-cell death (221) or differences in the form of tumor antigens used in these studies, [i.e., particulate (217) versus soluble (218)], which might be taken up by different DC subsets or recognized differently by the innate immune system.

Although TLR ligands have been tried as adjuvants to enhance vaccination efficiency for many years, very limited work has been done with NLR ligands. In a recent study, Garaude et al. demonstrated that introducing the bacterial protein flagellin, which activates TLR5, NAIP5, and NLRC4, into tumor-cell lines induced a potent $\mathrm{CD}^{+} \mathrm{T}$ cell anti-tumor adaptive immune response and thereby helped eliminate injected tumors. They additionally found that priming of tumor-specific $\mathrm{CD}^{+}$and $\mathrm{CD} 8^{+} \mathrm{T}$ cells by DCs was promoted by the dual triggering of TLR5 and NLRC4
(222). Therefore, under specific situations, NLR triggering, possibly in combination with other PRRs, crucially regulates adaptive immunity to altered host cells in tumors.

\section{CATEGORY 5: ADAPTIVE IMMUNITY TO FOREIGN SELF TARGETS}

Up to 100 trillion microbes inhabit the human intestinal tract, which is 10 -fold the number of human cells in the body. This ecosystem consists of fungi, bacteria, archaea, and viruses; most of these organisms are not pathogenic, but rather commensal, meaning that both the host and the organism benefit from cohabitation. Since these organisms function as a part of the human body and the immune system tolerates their presence, they can be thought of as an immune target that is both foreign but also self. A majority of these microbes can be found in the colon, where they contribute to the energy we extract from food, defend the mucosa against invading pathogens, induce the production of protective mucus and antimicrobial peptides as well as influence host immunity $(223,224)$. The microbiota is needed to adequately develop gut-associated lymphoid tissues by recruiting IgA-producing plasma cells and $\mathrm{CD} 4^{+} \mathrm{T}$ cells to the lamina propria and directing the development both of local lymphocyte subsets (224-226) including Th17 and Treg populations, as well as distal $\mathrm{B}$ cell and $\mathrm{T}$ cell zones in lymph nodes and the spleen (227). Accordingly, changes in the microbiota are believed to contribute to the development of intestinal diseases as well as systemic metabolic disorders.

To date NLRs, which are clearly present and highly active in the gut, have not been implicated in educating these intestinal lymphocyte populations. However, their activity can have a profound impact on the composition of the microbiota and loss of NLRs with the ensuing dysbiosis can impact both local and systemic immunity $(12,227)$. The gut immune system must be able to tolerate commensal microbes, while still being able to keep microbes from coming in close proximity to the epithelial cell layer and inducing damage; the ability of NLRs to identify pathogens that have breached cell membranes makes them well suited to act at this level of barrier function (Figure 1). Several examples have been described: decreased NLRP3 expression and defective NOD2 have been associated with Crohn's disease, in which the microbiota is believed to contribute to the intestinal inflammation (10, 228, 229); NLRP3 and NLRP6 deficiency lead to a high susceptibility to dextran sodium sulfate (DSS)-induced colitis $(54,230)$ and NLRP6 was shown to impact the composition of the microbiota leading to an intestinal dysbiosis that resulted in spontaneous intestinal inflammation (54). Huber et al. found an important role for NLRP3 and NLRP6 in regulating tissue repair and tumorigenesis in the colon through IL-18-dependent downregulation of dendritic cell-derived IL-22 binding protein (231). Conversely, inflammasome regulation of adaptive immunity at distal sites can be influenced by the gut microbiota. Ichinohe et al. demonstrated that commensal bacteria were critical for the induction of adaptive immune responses (including $\mathrm{CD} 4^{+} \mathrm{T}$ cell, $\mathrm{CD} 8^{+} \mathrm{T}$ cell, and antibody responses) to respiratory influenza infection by providing "signal 1" or the priming signal for inflammasome substrates pro-IL-1 $\beta$ and pro-IL-18 (232). 
However, the impact of NLRs on the induction of adaptive immune responses in the intestine needs further elucidation. We have previously proposed a "two-hit model" of PRR triggering to set thresholds for adaptive immunity in which DCs are primed by TLR activation but licensed by NLR activation (34). This model could also work to maintain homeostasis in the gut, in which the presence of microorganisms could lead to activation of TLRs, but activation of NLRs by DAMPS would be the decisive step in initiating an adaptive immune response.

\section{CONCLUSION}

Although a tremendous amount of work has been done resulting in significant advances regarding our understanding of NLR function over the past decade, there remains limited evidence that NLRs directly regulate adaptive immune responses. In ways distinct from TLR-driven pathways, NLRs indeed regulate aspects of DC migration, antigen presentation, and production of particular proinflammatory cytokines that can shape developing $\mathrm{T}$ cell responses (Figure 2). We have previously argued that this potentially represents a division of labor between two of the major subsets of PRRs, the TLRs and NLRs (34), although some NLRs can instigate inflammatory processes that overlap or modulate TLR-driven pathways to impact adaptive immunity. Yet for a majority of NLRs, including those identified through unbiased genetic screens such as NLRP1 (see Category 3: Adaptive Immunity to Self Targets), we do not know how these innate immune molecules function to instruct immunity. Given the location of these molecules and the distinct set of insults that stimulate their activity, it is not surprising that they have thus far been found to fulfill specialized but delimited functions in the intricate interplay between the innate and adaptive branches of the immune system.

\section{ACKNOWLEDGMENTS}

The authors would like to thank all members of the Eisenbarth lab along with S. Cassel and A. Williams for helpful discussion and review of this manuscript. This work was supported by K08AI085038, UL1RR024139, and a grant from The Hartwell Foundation.

\section{REFERENCES}

1. Janeway CA Jr. The immune system evolved to discriminate infectious nonself from noninfectious self. Immunol Today (1992) 13(1):11-6. doi:10.1016/01675699(92)90198-G

2. Takeuchi O, Akira S. Pattern recognition receptors and inflammation. Cell (2010) 140(6):805-20. doi:10.1016/j.cell.2010.01.022

3. Kawai T, Akira S. The role of pattern-recognition receptors in innate immunity: update on Toll-like receptors. Nat Immunol (2010) 11(5):373-84. doi:10.1038/ ni. 1863

4. Osorio F, Reis e Sousa C. Myeloid C-type lectin receptors in pathogen recognition and host defense. Immunity (2011) 34(5):651-64. doi:10.1016/j.immuni. 2011.05.001

5. Latz E, Xiao TS, Stutz A. Activation and regulation of the inflammasomes. Nat Rev Immunol (2013) 13(6):397-411. doi:10.1038/nri3452

6. Palm NW, Medzhitov R. Pattern recognition receptors and control of adaptive immunity. Immunol Rev (2009) 227(1):221-33. doi:10.1111/j.1600-065X. 2008.00731.x

7. Aoshi T, Koyama S, Kobiyama K, Akira S, Ishii KJ. Innate and adaptive immune responses to viral infection and vaccination. Curr Opin Virol (2011) 1(4):226-32. doi:10.1016/j.coviro.2011.07.002

8. Travassos LH, Carneiro LA, Ramjeet M, Hussey S, Kim YG, Magalhães JG, et al. Nod1 and Nod2 direct autophagy by recruiting ATG16L1 to the plasma membrane at the site of bacterial entry. Nat Immunol (2010) 11(1):55-62. doi:10.1038/ni.1823

9. Girardin SE, Boneca IG, Carneiro LA, Antignac A, Jéhanno M, Viala J, et al. Nodl detects a unique muropeptide from Gram-negative bacterial peptidoglycan. Science (2003) 300(5625):1584-7. doi:10.1126/science.1084677

10. Ogura Y, Bonen DK, Inohara N, Nicolae DL, Chen FF, Ramos R, et al. A frameshift mutation in NOD2 associated with susceptibility to Crohn's disease. Nature (2001) 411(6837):603-6. doi:10.1038/35079114

11. Girardin SE, Boneca IG, Viala J, Chamaillard M, Labigne A, Thomas G, et al. Nod2 is a general sensor of peptidoglycan through muramyl dipeptide (MDP) detection. J Biol Chem (2003) 278(11):8869-72. doi:10.1074/jbc.C200651200

12. Boyle JP, Mayle S, Parkhouse R, Monie TP. Comparative genomic and sequence analysis provides insight into the molecular functionality of NOD1 and NOD2. Front Immunol (2013) 4:317. doi:10.3389/fimmu.2013.00317

13. Arthur JC, Lich JD, Ye Z, Allen IC, Gris D, Wilson JE, et al. Cutting edge: NLRP12 controls dendritic and myeloid cell migration to affect contact hypersensitivity. J Immunol (2010) 185(8):4515-9. doi:10.4049/jimmunol.1002227

14. Eisenbarth SC, Williams A, Colegio OR, Meng H, Strowig T, Rongvaux A, et al. NLRP10 is a NOD-like receptor essential to initiate adaptive immunity by dendritic cells. Nature (2012) 484(7395):510-3. doi:10.1038/nature11012

15. LeibundGut-Landmann S, Waldburger JM, Krawczyk M, Otten LA, Suter T, Fontana A, et al. Mini-review: specificity and expression of CIITA, the master regulator of MHC class II genes. Eur J Immunol (2004) 34(6):1513-25. doi:10.1002/eji.200424964

16. Kobayashi KS, van den Elsen PJ. NLRC5: a key regulator of MHC class I-dependent immune responses. Nat Rev Immunol (2012) 12(12):813-20. doi:10.1038/nri3339

17. Kumar H, Pandey S, Zou J, Kumagai Y, Takahashi K, Akira S, et al. NLRC5 deficiency does not influence cytokine induction by virus and bacteria infections. J Immunol (2011) 186(2):994-1000. doi:10.4049/jimmunol.1002094

18. Yao Y, Wang Y, Chen F, Huang Y, Zhu S, Leng Q, et al. NLRC5 regulates MHC class I antigen presentation in host defense against intracellular pathogens. Cell Res (2012) 22(5):836-47. doi:10.1038/cr.2012.56

19. Davis BK, Roberts RA, Huang MT, Willingham SB, Conti BJ, Brickey WJ, et al. Cutting edge: NLRC5-dependent activation of the inflammasome. J Immunol (2011) 186(3):1333-7. doi:10.4049/jimmunol.1003111

20. Kufer TA, Sansonetti PJ. NLR functions beyond pathogen recognition. Nat Immunol (2011) 12(2):121-8. doi:10.1038/ni.1985

21. Ting JP, Lovering RC, Alnemri ES, Bertin J, Boss JM, Davis BK, et al. The NLR gene family: a standard nomenclature. Immunity (2008) 28(3):285-7. doi:10.1016/j.immuni.2008.02.005

22. Schroder K, Tschopp J. The inflammasomes. Cell (2010) 140(6):821-32. doi:10.1016/j.cell.2010.01.040

23. Mo J, Boyle JP, Howard CB, Monie TP, Davis BK, Duncan JA. Pathogen sensing by nucleotide-binding oligomerization domain-containing protein 2 (NOD2) is mediated by direct binding to muramyl dipeptide and ATP. J Biol Chem (2012) 287(27):23057-67. doi:10.1074/jbc.M112.344283

24. Tanabe T, Chamaillard M, Ogura Y, Zhu L, Qiu S, Masumoto J, et al. Regulatory regions and critical residues of NOD2 involved in muramyl dipeptide recognition. EMBO J (2004) 23(7):1587-97. doi:10.1038/sj.emboj. 7600175

25. Lightfield KL, Persson J, Trinidad NJ, Brubaker SW, Kofoed EM, Sauer JD, et al. Differential requirements for NAIP5 in activation of the NLRC4 inflammasome. Infect Immun (2011) 79(4):1606-14. doi:10.1128/IAI.01187-10

26. Grimes CL, Ariyananda Lde Z, Melnyk JE, O'Shea EK. The innate immune protein Nod2 binds directly to MDP, a bacterial cell wall fragment. J Am Chem Soc (2012) 134(33):13535-7. doi:10.1021/ja303883c

27. Laroui H, Yan Y, Narui Y, Ingersoll SA, Ayyadurai S, Charania MA, et al. LAla-gamma-D-Glu-meso-diaminopimelic acid (DAP) interacts directly with leucine-rich region domain of nucleotide-binding oligomerization domain 1 , increasing phosphorylation activity of receptor-interacting serine/threonineprotein kinase 2 and its interaction with nucleotide-binding oligomerization domain 1. J Biol Chem (2011) 286(35):31003-13. doi:10.1074/jbc.M111. 257501

28. Ting JPY, Duncan JA, Lei Y. How the noninflammasome NLRs function in the innate immune system. Science (2010) 327(5963):286-90. doi:10.1126/science. 1184004

29. Halff EF, Diebolder CA, Versteeg M, Schouten A, Brondijk TH, Huizinga EG. Formation and structure of a NAIP5-NLRC4 inflammasome induced by direct 
interactions with conserved $\mathrm{N}$ - and C-terminal regions of flagellin. J Biol Chem (2012) 287(46):38460-72. doi:10.1074/jbc.M112.393512

30. Faustin B, Lartigue L, Bruey JM, Luciano F, Sergienko E, Bailly-Maitre B, et al. Reconstituted NALP1 inflammasome reveals two-step mechanism of caspase-1 activation. Mol Cell (2007) 25(5):713-24. doi:10.1016/j.molcel.2007. 01.032

31. Danot O, Marquenet E, Vidal-Ingigliardi D, Richet E. Wheel of life, wheel of death: a mechanistic insight into signaling by STAND proteins. Structure (2009) 17(2):172-82. doi:10.1016/j.str.2009.01.001

32. Hu Z, Yan C, Liu P, Huang Z, Ma R, Zhang C, et al. Crystal structure of NLRC4 reveals its autoinhibition mechanism. Science (2013) 341(6142):172-5. doi:10.1126/science.1236381

33. Kofoed EM, Vance RE. Innate immune recognition of bacterial ligands by NAIPs determines inflammasome specificity. Nature (2011) 477(7366):592-5. doi:10.1038/nature10394

34. Krishnaswamy JK, Chu TC, Eisenbarth SC. Beyond pattern recognition: NOD-like receptors in dendritic cells. Trends Immunol (2013) 34(5):224-33. doi:10.1016/j.it.2012.12.003

35. Leemans JC, Cassel SL, Sutterwala FS. Sensing damage by the NLRP3 inflammasome. Immunol Rev (2011) 243(1):152-62. doi:10.1111/j.1600-065X.2011. 01043.x

36. Lee GS, Subramanian N, Kim AI, Aksentijevich I, Goldbach-Mansky R, Sacks $\mathrm{DB}$, et al. The calcium-sensing receptor regulates the NLRP3 inflammasome through Ca2+ and cAMP. Nature (2012) 492(7427):123-7. doi:10.1038/ nature 11588

37. Zhong Z, Zhai Y, Liang S, Mori Y, Han R, Sutterwala FS, et al. TRPM2 links oxidative stress to NLRP3 inflammasome activation. Nat Commun (2013) 4:1611. doi:10.1038/ncomms 2608

38. Murakami T, Ockinger J, Yu J, Byles V, McColl A, Hofer AM, et al. Critical role for calcium mobilization in activation of the NLRP3 inflammasome. Proc Natl Acad Sci U S A (2012) 109(28):11282-7. doi:10.1073/pnas.1117765109

39. Jun HK, Lee SH, Lee HR, Choi BK. Integrin alpha5betal activates the NLRP3 inflammasome by direct interaction with a bacterial surface protein. Immunity (2012) 36(5):755-68. doi:10.1016/j.immuni.2012.05.002

40. Schorn C, Frey B, Lauber K, Janko C, Strysio M, Keppeler H, et al. Sodium overload and water influx activate the NALP3 inflammasome. J Biol Chem (2011) 286(1):35-41. doi:10.1074/jbc.M110.139048

41. Compan V, Baroja-Mazo A, López-Castejón G, Gomez AI, Martínez CM, Angosto D, et al. Cell volume regulation modulates NLRP3 inflammasome activation. Immunity (2012) 37(3):487-500. doi:10.1016/j.immuni.2012.06.013

42. Muñoz-Planillo R, Kuffa P, Martínez-Colón G, Smith BL, Rajendiran TM, Núñez G. $\mathrm{K}(+)$ efflux is the common trigger of NLRP3 inflammasome activation by bacterial toxins and particulate matter. Immunity (2013) 38(6):1142-53. doi:10.1016/j.immuni.2013.05.016

43. Lu B, Nakamura T, Inouye K, Li J, Tang Y, Lundbäck P, et al. Novel role of PKR in inflammasome activation and HMGB1 release. Nature (2012) 488(7413):670-4. doi:10.1038/nature11290

44. Zhou R, Yazdi AS, Menu P, Tschopp J. A role for mitochondria in NLRP3 inflammasome activation. Nature (2011) 469(7329):221-5. doi:10.1038/nature09663

45. Nakahira K, Haspel JA, Rathinam VA, Lee SJ, Dolinay T, Lam HC, et al. Autophagy proteins regulate innate immune responses by inhibiting the release of mitochondrial DNA mediated by the NALP3 inflammasome. Nat Immunol (2010) 12(3):222-30. doi:10.1038/ni.1980

46. Shimada K, Crother TR, Karlin J, Dagvadorj J, Chiba N, Chen S, et al. Oxidized mitochondrial DNA activates the NLRP3 inflammasome during apoptosis. Immunity (2012) 36(3):401-14. doi:10.1016/j.immuni.2012.01.009

47. Misawa T, Takahama M, Kozaki T, Lee H, Zou J, Saitoh T, et al. Microtubuledriven spatial arrangement of mitochondria promotes activation of the NLRP3 inflammasome. Nat Immunol (2013) 14(5):454-60. doi:10.1038/ni. 2550

48. Subramanian N, Natarajan K, Clatworthy MR, Wang Z, Germain RN. The adaptor MAVS promotes NLRP3 mitochondrial localization and inflammasome activation. Cell (2013) 153(2):348-61. doi:10.1016/j.cell.2013.02.054

49. Lupfer C, Thomas PG, Anand PK, Vogel P, Milasta S, Martinez J, et al. Receptor interacting protein kinase 2-mediated mitophagy regulates inflammasome activation during virus infection. Nat Immunol (2013) 14(5):480-8. doi:10.1038/ni.2563
50. Iyer SS, Pulskens WP, Sadler JJ, Butter LM, Teske GJ, Ulland TK, et al. Necrotic cells trigger a sterile inflammatory response through the Nlrp3 inflammasome. Proc Natl Acad Sci USA (2009) 106(48):20388-93. doi:10.1073/pnas. 0908698106

51. Haneklaus M, O'Neill LA, Coll RC. Modulatory mechanisms controlling the NLRP3 inflammasome in inflammation: recent developments. Curr Opin Immunol (2013) 25(1):40-5. doi:10.1016/j.coi.2012.12.004

52. Licandro G, Ling Khor H, Beretta O, Lai J, Derks H, Laudisi F, et al. The NLRP3 inflammasome affects DNA damage responses after oxidative and genotoxic stress in dendritic cells. Eur J Immunol (2013) 43(8):2126-37. doi:10.1002/eji.201242918

53. Khare S, Dorfleutner A, Bryan NB, Yun C, Radian AD, de Almeida L, et al. An NLRP7-containing inflammasome mediates recognition of microbial lipopeptides in human macrophages. Immunity (2012) 36(3):464-76. doi:10.1016/j.immuni.2012.02.001

54. Elinav E, Strowig T, Kau AL, Henao-Mejia J, Thaiss CA, Booth CJ, et al. NLRP6 inflammasome regulates colonic microbial ecology and risk for colitis. Cell (2011) 145(5):745-57. doi:10.1016/j.cell.2011.04.022

55. Wang L, Manji GA, Grenier JM, Al-Garawi A, Merriam S, Lora JM, et al. PYPAF7, a novel PYRIN-containing Apaf1-like protein that regulates activation of NF- $\mathrm{\kappa B}$ and caspase-1-dependent cytokine processing. J Biol Chem (2002) 277(33):29874-80. doi:10.1074/jbc.M203915200

56. Strowig T, Henao-Mejia J, Elinav E, Flavell R. Inflammasomes in health and disease. Nature (2012) 481(7381):278-86. doi:10.1038/nature10759

57. Broz P, von Moltke J, Jones JW, Vance RE, Monack DM. Differential requirement for Caspase-1 autoproteolysis in pathogen-induced cell death and cytokine processing. Cell Host Microbe (2010) 8(6):471-83. doi:10.1016/j.chom.2010.11.007

58. Mariathasan S, Newton K, Monack DM, Vucic D, French DM, Lee WP, et al. Differential activation of the inflammasome by caspase- 1 adaptors ASC and Ipaf. Nature (2004) 430(6996):213-8. doi:10.1038/nature02664

59. Sutterwala FS, Mijares LA, Li L, Ogura Y, Kazmierczak BI, Flavell RA. Immune recognition of Pseudomonas aeruginosa mediated by the IPAF/NLRC4 inflammasome. J Exp Med (2007) 204(13):3235-45. doi:10.1084/jem.20071239

60. Jin T, Perry A, Jiang J, Smith P, Curry JA, Unterholzner L, et al. Structures of the HIN domain:DNA complexes reveal ligand binding and activation mechanisms of the AIM2 inflammasome and IFI16 receptor. Immunity (2012) 36(4):561-71. doi:10.1016/j.immuni.2012.02.014

61. Kayagaki N, Warming S, Lamkanfi M, Vande Walle L, Louie S, Dong J, et al. Non-canonical inflammasome activation targets caspase-11. Nature (2011) 479(7371):117-21. doi:10.1038/nature10558

62. Rathinam VA, Vanaja SK, Waggoner L, Sokolovska A, Becker C, Stuart LM, et al. TRIF licenses caspase-11-dependent NLRP3 inflammasome activation by Gram-negative bacteria. Cell (2012) 150(3):606-19. doi:10.1016/j.cell.2012. 07.007

63. Aachoui Y, Leaf IA, Hagar JA, Fontana MF, Campos CG, Zak DE, et al. Caspase-11 protects against bacteria that escape the vacuole. Science (2013) 339(6122):975-8. doi:10.1126/science.1230751

64. Hart DN. Dendritic cells: unique leukocyte populations which control the primary immune response. Blood (1997) 90(9):3245-87.

65. Banchereau J, Steinman RM. Dendritic cells and the control of immunity. Nature (1998) 392(6673):245-52. doi:10.1038/32588

66. Fritz JH, Le Bourhis L, Sellge G, Magalhaes JG, Fsihi H, Kufer TA, et al. Nod1mediated innate immune recognition of peptidoglycan contributes to the onset of adaptive immunity. Immunity (2007) 26(4):445-59. doi:10.1016/j.immuni. 2007.03.009

67. Schwarz H, Posselt G, Wurm P, Ulbing M, Duschl A, Horejs-Hoeck J. TLR8 and NOD signaling synergistically induce the production of IL-1beta and IL- 23 in monocyte-derived DCs and enhance the expression of the feedback inhibitor SOCS2. Immunobiology (2013) 218(4):533-42. doi:10.1016/j.imbio.2012.06. 007

68. Joly S, Eisenbarth SC, Olivier AK, Williams A, Kaplan DH, Cassel SL, et al. Cutting edge: Nlrp10 is essential for protective antifungal adaptive immunity against Candida albicans. J Immunol (2012) 189(10):4713-7. doi:10.4049/ jimmunol.1201715

69. Mitchell AM, Mitchell TJ. Streptococcus pneumoniae: virulence factors and variation. Clin Microbiol Infect (2010) 16(5):411-8. doi:10.1111/j.1469-0691.2010. 03183.x 
70. Koedel U, Winkler F, Angele B, Fontana A, Flavell RA, Pfister HW. Role of Caspase-1 in experimental Pneumococcal meningitis: evidence from pharmacologic caspase inhibition and caspase-1-deficient mice. Ann Neurol (2002) 51(3):319-29. doi:10.1002/ana.10103

71. Shoma S, Tsuchiya K, Kawamura I, Nomura T, Hara H, Uchiyama R, et al. Critical involvement of pneumolysin in production of interleukin-1alpha and caspase-1-dependent cytokines in infection with Streptococcus pneumoniae in vitro: a novel function of pneumolysin in caspase-1 activation. Infect Immun (2008) 76(4):1547-57. doi:10.1128/IAI.01269-07

72. McNeela EA, Burke A, Neill DR, Baxter C, Fernandes VE, Ferreira D, et al. Pneumolysin activates the NLRP3 inflammasome and promotes proinflammatory cytokines independently of TLR4. PLoS Pathog (2010) 6(11):e1001191. doi:10.1371/journal.ppat.1001191

73. Witzenrath M, Pache F, Lorenz D, Koppe U, Gutbier B, Tabeling C, et al. The NLRP3 inflammasome is differentially activated by pneumolysin variants and contributes to host defense in pneumococcal pneumonia. J Immunol (2011) 187(1):434-40. doi:10.4049/jimmunol.1003143

74. Neerincx A, Lautz K, Menning M, Kremmer E, Zigrino P, Hösel M, et al. A role for the human nucleotide-binding domain, leucine-rich repeat-containing family member NLRC5 in antiviral responses. J Biol Chem (2010) 285(34):26223-32. doi:10.1074/jbc.M110.109736

75. Meissner TB, Li A, Biswas A, Lee KH, Liu YJ, Bayir E, et al. NLR family member NLRC5 is a transcriptional regulator of MHC class I genes. Proc Natl Acad Sci U S A (2010) 107(31):13794-9. doi:10.1073/pnas.1008684107

76. McElvania Tekippe E, Allen IC, Hulseberg PD, Sullivan JT, McCann JR, Sandor $\mathrm{M}$, et al. Granuloma formation and host defense in chronic Mycobacterium tuberculosis infection requires PYCARD/ASC but not NLRP3 or caspase-1. PLoS One (2010) 5(8):e12320. doi:10.1371/journal.pone.0012320

77. Walter K, Hölscher C, Tschopp J, Ehlers S. NALP3 is not necessary for early protection against experimental tuberculosis. Immunobiology (2010) 215(9-10):804-11. doi:10.1016/j.imbio.2010.05.015

78. Novikov A, Cardone M, Thompson R, Shenderov K, Kirschman KD, MayerBarber KD, et al. Mycobacterium tuberculosis triggers host type I IFN signaling to regulate IL-1beta production in human macrophages. J Immunol (2011) 187(5):2540-7. doi:10.4049/jimmunol.1100926

79. Mayer-Barber KD, Barber DL, Shenderov K, White SD, Wilson MS, Cheever A, et al. Caspase-1 independent IL-1beta production is critical for host resistance to Mycobacterium tuberculosis and does not require TLR signaling in vivo. J Immunol (2010) 184(7):3326-30. doi:10.4049/jimmunol.0904189

80. Shenderov K, Barber DL, Mayer-Barber KD, Gurcha SS, Jankovic D, Feng CG, et al. Cord factor and peptidoglycan recapitulate the Th17-promoting adjuvant activity of mycobacteria through mincle/CARD9 signaling and the inflammasome. J Immunol (2013) 190(11):5722-30. doi:10.4049/jimmunol.1203343

81. Gross O, Yazdi AS, Thomas CJ, Masin M, Heinz LX, Guarda G, et al. Inflammasome activators induce interleukin-lalpha secretion via distinct pathways with differential requirement for the protease function of caspase-1. Immunity (2012) 36(3):388-400. doi:10.1016/j.immuni.2012.01.018

82. Mayer-Barber KD, Andrade BB, Barber DL, Hieny S, Feng CG, Caspar P, et al. Innate and adaptive interferons suppress IL-1alpha and IL-1beta production by distinct pulmonary myeloid subsets during Mycobacterium tuberculosis infection. Immunity (2011) 35(6):1023-34. doi:10.1016/j.immuni.2011.12.002

83. Kupz A, Guarda G, Gebhardt T, Sander LE, Short KR, Diavatopoulos DA, et al. NLRC4 inflammasomes in dendritic cells regulate noncognate effector function by memory CD8(+) T cells. Nat Immunol (2012) 13(2):162-9. doi:10.1038/ni.2195

84. Hitzler I, Sayi A, Kohler E, Engler DB, Koch KN, Hardt WD, et al. Caspase-1 has both proinflammatory and regulatory properties in Helicobacter infections, which are differentially mediated by its substrates IL-1beta and IL-18. J Immunol (2012) 188(8):3594-602. doi:10.4049/jimmunol.1103212

85. Pedra JH, Sutterwala FS, Sukumaran B, Ogura Y, Qian F, Montgomery RR, et al. ASC/PYCARD and caspase-1 regulate the IL-18/IFN-gamma axis during Anaplasma phagocytophilum infection. J Immunol (2007) 179(7): 4783-91.

86. Perez-Lopez A, Rosales-Reyes R, Alpuche-Aranda CM, Ortiz-Navarrete V. Salmonella downregulates Nod-like receptor family CARD domain containing protein 4 expression to promote its survival in B cells by preventing inflammasome activation and cell death. J Immunol (2013) 190(3):1201-9. doi:10.4049/jimmunol.1200415
87. Jacobs SR, Damania B. NLRs, inflammasomes, and viral infection. J Leukoc Biol (2012) 92(3):469-77. doi:10.1189/jlb.0312132

88. Kanneganti TD. Central roles of NLRs and inflammasomes in viral infection. Nat Rev Immunol (2010) 10(10):688-98. doi:10.1038/nri2851

89. Franchi L, Munoz-Planillo R, Nunez G. Sensing and reacting to microbes through the inflammasomes. Nat Immunol (2012) 13(4):325-32. doi:10.1038/ ni. 2231

90. Ichinohe T, Pang IK, Iwasaki A. Influenza virus activates inflammasomes via its intracellular M2 ion channel. Nat Immunol (2010) 11(5):404-10. doi:10.1038/ni.1861

91. Schmitz N, Kurrer M, Bachmann MF, Kopf M. Interleukin-1 is responsible for acute lung immunopathology but increases survival of respiratory influenza virus infection. J Virol (2005) 79(10):6441-8. doi:10.1128/JVI.79. 10.6441-6448.2005

92. Ichinohe T, Lee HK, Ogura Y, Flavell R, Iwasaki A. Inflammasome recognition of influenza virus is essential for adaptive immune responses. J Exp Med (2009) 206(1):79-87. doi:10.1084/jem.20081667

93. Stout-Delgado HW, Vaughan SE, Shirali AC, Jaramillo RJ, Harrod KS. Impaired NLRP3 inflammasome function in elderly mice during influenza infection is rescued by treatment with nigericin. J Immunol (2012) 188(6):2815-24. doi:10.4049/jimmunol.1103051

94. Schneider-Ohrum K, Giles BM, Weirback HK, Williams BL, DeAlmeida DR, Ross TM. Adjuvants that stimulate TLR3 or NLPR3 pathways enhance the efficiency of influenza virus-like particle vaccines in aged mice. Vaccine (2011) 29(48):9081-92. doi:10.1016/j.vaccine.2011.09.051

95. Allen IC, Scull MA, Moore CB, Holl EK, McElvania-TeKippe E, Taxman DJ, et al. The NLRP3 inflammasome mediates in vivo innate immunity to influenza A virus through recognition of viral RNA. Immunity (2009) 30(4):556-65. doi:10.1016/j.immuni.2009.02.005

96. Thomas PG, Dash P, Aldridge JR Jr, Ellebedy AH, Reynolds C, Funk AJ, et al. The intracellular sensor NLRP3 mediates key innate and healing responses to influenza A virus via the regulation of caspase-1. Immunity (2009) 30(4):566-75. doi:10.1016/j.immuni.2009.02.006

97. Pang IK, Ichinohe T, Iwasaki A. IL-1R signaling in dendritic cells replaces pattern-recognition receptors in promoting $\mathrm{CD} 8(+) \mathrm{T}$ cell responses to influenza A virus. Nat Immunol (2013) 14(3):246-53. doi:10.1038/ni.2514

98. Ramos HJ, Lanteri MC, Blahnik G, Negash A, Suthar MS, Brassil MM, et al. IL-1beta signaling promotes CNS-intrinsic immune control of West Nile virus infection. PLoS Pathog (2012) 8(11):e1003039. doi:10.1371/journal.ppat. 1003039

99. Lima-Junior DS, Costa DL, Carregaro V, Cunha LD, Silva AL, Mineo TW, et al. Inflammasome-derived IL-1beta production induces nitric oxide-mediated resistance to Leishmania. Nat Med (2013) 19(7):909-15. doi:10.1038/nm.3221

100. Shio MT, Eisenbarth SC, Savaria M, Vinet AF, Bellemare MJ, Harder KW, et al. Malarial hemozoin activates the NLRP3 inflammasome through Lyn and Syk kinases. PLoS Pathog (2009) 5(8):e1000559. doi:10.1371/journal.ppat.1000559

101. Ritter M, Gross O, Kays S, Ruland J, Nimmerjahn F, Saijo S, et al. Schistosoma mansoni triggers Dectin-2, which activates the Nlrp3 inflammasome and alters adaptive immune responses. Proc Natl Acad Sci US A (2010) 107(47):20459-64. doi:10.1073/pnas.1010337107

102. Joly S, Ma N, Sadler JJ, Soll DR, Cassel SL, Sutterwala FS. Cutting edge: Candida albicans hyphae formation triggers activation of the Nlrp3 inflammasome. J Immunol (2009) 183(6):3578-81. doi:10.4049/jimmunol.0901323

103. Hise AG, Tomalka J, Ganesan S, Patel K, Hall BA, Brown GD, et al. An essential role for the NLRP3 inflammasome in host defense against the human fungal pathogen Candida albicans. Cell Host Microbe (2009) 5(5):487-97. doi:10.1016/j.chom.2009.05.002

104. Gross O, Poeck H, Bscheider M, Dostert C, Hannesschläger N, Endres S, et al. Syk kinase signalling couples to the Nlrp3 inflammasome for anti-fungal host defence. Nature (2009) 459(7245):433-6. doi:10.1038/nature07965

105. van de Veerdonk FL, Joosten LA, Shaw PJ, Smeekens SP, Malireddi RK, van der Meer JW, et al. The inflammasome drives protective Th1 and Th17 cellular responses in disseminated Candidiasis. Eur J Immunol (2011) 41(8):2260-8. doi:10.1002/eji.201041226

106. Mencacci A, Bacci A, Cenci E, Montagnoli C, Fiorucci S, Casagrande A, et al. Interleukin 18 restores defective Th1 immunity to Candida albicans in caspase 1-deficient mice. Infect Immun (2000) 68(9):5126-31. doi:10.1128/IAI.68.9. 5126-5131.2000 
107. Eisenbarth SC, Colegio OR, O'Connor W, Sutterwala FS, Flavell RA. Crucial role for the Nalp3 inflammasome in the immunostimulatory properties of aluminium adjuvants. Nature (2008) 453(7198):1122-6. doi:10.1038/ nature06939

108. Franchi L, Núñez G. The Nlrp3 inflammasome is critical for aluminium hydroxide-mediated IL-1beta secretion but dispensable for adjuvant activity. Eur J Immunol (2008) 38(8):2085-9. doi:10.1002/eji.200838549

109. Kool M, Pétrilli V, De Smedt T, Rolaz A, Hammad H, van Nimwegen M, et al. Cutting edge: alum adjuvant stimulates inflammatory dendritic cells through activation of the NALP3 inflammasome. J Immunol (2008) 181(6):3755-9.

110. Li H, Willingham SB, Ting JP, Re F. Cutting edge: inflammasome activation by alum and alum's adjuvant effect are mediated by NLRP3. J Immunol (2008) 181(1):17-21. doi:10.1111/j.1365-2567.2007.02774.x

111. McKee AS, Munks MW, MacLeod MK, Fleenor CJ, Van Rooijen N, Kappler JW, et al. Alum induces innate immune responses through macrophage and mast cell sensors, but these sensors are not required for alum to act as an adjuvant for specific immunity. J Immunol (2009) 183(7):4403-14. doi:10.4049/jimmunol.0900164

112. Lambrecht BN, Kool M, Willart MA, Hammad H. Mechanism of action of clinically approved adjuvants. Curr Opin Immunol (2009) 21(1):23-9. doi:10.1016/j.coi.2009.01.004

113. Allen IC, Jania CM, Wilson JE, Tekeppe EM, Hua X, Brickey WJ, et al. Analysis of NLRP3 in the development of allergic airway disease in mice. J Immunol (2012) 188(6):2884-93. doi:10.4049/jimmunol.1102488

114. Idzko M, Hammad H, van Nimwegen M, Kool M, Willart MA, Muskens F, et al. Extracellular ATP triggers and maintains asthmatic airway inflammation by activating dendritic cells. Nat Med (2007) 13(8):913-9. doi:10.1038/ $\mathrm{nm} 1617$

115. Kool M, van Loo G, Waelput W, De Prijck S, Muskens F, Sze M, et al. The ubiquitin-editing protein A20 prevents dendritic cell activation, recognition of apoptotic cells, and systemic autoimmunity. Immunity (2011) 35(1):82-96. doi:10.1016/j.immuni.2011.05.013

116. Marichal T, Ohata K, Bedoret D, Mesnil C, Sabatel C, Kobiyama K, et al. DNA released from dying host cells mediates aluminum adjuvant activity. Nat Med (2011) 17(8):996-1002. doi:10.1038/nm.2403

117. Jacobson LS, Lima H Jr, Goldberg MF, Gocheva V, Tsiperson V, Sutterwala FS, et al. Cathepsin-mediated necrosis controls the adaptive immune response by Th2 (T helper type 2)-associated adjuvants. J Biol Chem (2013) 288(11):7481-91. doi:10.1074/jbc.M112.400655

118. Ellebedy AH, Lupfer C, Ghoneim HE, DeBeauchamp J, Kanneganti TD, Webby RJ. Inflammasome-independent role of the apoptosis-associated speck-like protein containing CARD (ASC) in the adjuvant effect of MF59. Proc Natl Acad Sci U S A (2011) 108(7):2927-32. doi:10.1073/pnas. 1012455108

119. Seubert A, Calabro S, Santini L, Galli B, Genovese A, Valentini S, et al. Adjuvanticity of the oil-in-water emulsion MF59 is independent of Nlrp3 inflammasome but requires the adaptor protein MyD88. Proc Natl Acad Sci U S A (2011) 108(27):11169-74. doi:10.1073/pnas.1107941108

120. Dupuis M, Murphy TJ, Higgins D, Ugozzoli M, van Nest G, Ott G, et al. Dendritic cells internalize vaccine adjuvant after intramuscular injection. Cell Immunol (1998) 186(1):18-27. doi:10.1006/cimm.1998.1283

121. Calabro S, Tortoli M, Baudner BC, Pacitto A, Cortese M, O’Hagan DT, et al. Vaccine adjuvants alum and MF59 induce rapid recruitment of neutrophils and monocytes that participate in antigen transport to draining lymph nodes. Vaccine (2011) 29(9):1812-23. doi:10.1016/j.vaccine.2010.12.090

122. Hamdy S, Molavi O, Ma Z, Haddadi A, Alshamsan A, Gobti Z, et al. Co-delivery of cancer-associated antigen and Toll-like receptor 4 ligand in PLGA nanoparticles induces potent CD8+ T cell-mediated anti-tumor immunity. Vaccine (2008) 26(39):5046-57. doi:10.1016/j.vaccine.2008.07.035

123. Demento SL, Eisenbarth SC, Foellmer HG, Platt C, Caplan MJ, Mark Saltzman $\mathrm{W}$, et al. Inflammasome-activating nanoparticles as modular systems for optimizing vaccine efficacy. Vaccine (2009) 27(23):3013-21. doi:10.1016/j.vaccine. 2009.03.034

124. Sharp FA, Ruane D, Claass B, Creagh E, Harris J, Malyala P, et al. Uptake of particulate vaccine adjuvants by dendritic cells activates the NALP3 inflammasome. Proc Natl Acad Sci U S A (2009) 106(3):870-5. doi:10.1073/pnas. 0804897106

125. Meraz IM, Melendez B, Gu J, Wong ST, Liu X, Andersson HA, et al. Activation of the inflammasome and enhanced migration of microparticle-stimulated dendritic cells to the draining lymph node. Mol Pharm (2012) 9(7):2049-62. doi:10.1021/mp3001292

126. Palm NW, Rosenstein RK, Medzhitov R. Allergic host defences. Nature (2012) 484(7395):465-72. doi:10.1038/nature11047

127. Eisenbarth SC, Cassel S, Bottomly K. Understanding asthma pathogenesis: linking innate and adaptive immunity. Curr Opin Pediatr (2004) 16(6):659-66. doi:10.1097/01.mop.0000145920.00101.e4

128. Trompette A, Divanovic S, Visintin A, Blanchard C, Hegde RS, Madan R, et al. Allergenicity resulting from functional mimicry of a Toll-like receptor complex protein. Nature (2009) 457(7229):585-8. doi:10.1038/nature07548

129. Palm NW, Medzhitov R. Role of the inflammasome in defense against venoms. Proc Natl Acad Sci U S A (2013) 110(5):1809-14. doi:10.1073/pnas.1221476110

130. Tjota MY, Williams JW, Lu T, Clay BS, Byrd T, Hrusch CL, et al. IL-33dependent induction of allergic lung inflammation by FcgammaRIII signaling. J Clin Invest (2013) 123(5):2287-97. doi:10.1172/JCI63802

131. Wills-Karp M, Rani R, Dienger K, Lewkowich I, Fox JG, Perkins C, et al. Trefoil factor 2 rapidly induces interleukin 33 to promote type 2 immunity during allergic asthma and hookworm infection. J Exp Med (2012) 209(3):607-22. doi:10.1084/jem.20110079

132. Hsu CL, Bryce PJ. Inducible IL-33 expression by mast cells is regulated by a calcium-dependent pathway. J Immunol (2012) 189(7):3421-9. doi:10.4049/ jimmunol.1201224

133. Kurowska-Stolarska M, Kewin P, Murphy G, Russo RC, Stolarski B, Garcia CC, et al. IL-33 induces antigen-specific IL-5+ T cells and promotes allergic-induced airway inflammation independent of IL-4. J Immunol (2008) 181(7):4780-90.

134. Cayrol C, Girard JP. The IL-1-like cytokine IL-33 is inactivated after maturation by caspase-1. Proc Natl Acad Sci U S A (2009) 106(22):9021-6. doi:10.1073/pnas.0812690106

135. Lüthi AU, Cullen SP, McNeela EA, Duriez PJ, Afonina IS, Sheridan C, et al. Suppression of interleukin-33 bioactivity through proteolysis by apoptotic caspases. Immunity (2009) 31(1):84-98. doi:10.1016/j.immuni.2009.05.007

136. Ali S, Nguyen DQ, Falk W, Martin MU. Caspase 3 inactivates biologically active full length interleukin-33 as a classical cytokine but does not prohibit nuclear translocation. Biochem Biophys Res Commun (2010) 391(3):1512-6. doi:10.1016/j.bbrc.2009.12.107

137. Pattaro C, Heinrich J, Werner M, de Marco R, Wjst M. Association between interleukin-1 receptor antagonist gene and asthma-related traits in a German adult population. Allergy (2006) 61(2):239-44. doi:10.1111/j.1398-9995.2006. 00988.x

138. Ma Y, Zhang B, Tang RK, Liu Y, Peng GG. Interleukin-18 promoter polymorphism and asthma risk: a meta-analysis. Mol Biol Rep (2012) 39(2):1371-6. doi:10.1007/s11033-011-0871-6

139. Eisenbarth SC. Use and limitations of alum-based models of allergy. Clin Exp Allergy (2008) 38(10):1572-5. doi:10.1111/j.1365-2222.2008.03069.x

140. Schmitz N, Kurrer M, Kopf M. The IL-1 receptor 1 is critical for Th2 cell type airway immune responses in a mild but not in a more severe asthma model. Eur J Immunol (2003) 33(4):991-1000. doi:10.1002/eji.200323801

141. Allen IC, Lich JD, Arthur JC, Jania CM, Roberts RA, Callaway JB, et al. Characterization of NLRP12 during the development of allergic airway disease in mice. PLoS One (2012) 7(1):e30612. doi:10.1371/journal.pone.0030612

142. Nakae S, Komiyama Y, Yokoyama H, Nambu A, Umeda M, Iwase M, et al. IL-1 is required for allergen-specific Th2 cell activation and the development of airway hypersensitivity response. Int Immunol (2003) 15(4):483-90. doi:10.1093/intimm/dxg054

143. Martin RA, Ather JL, Lundblad LK, Suratt BT, Boyson JE, Budd RC, et al. Interleukin-1 receptor and caspase-1 are required for the Th17 response in nitrogen dioxide-promoted allergic airway disease. Am J Respir Cell Mol Biol (2013) 48(5):655-64. doi:10.1165/rcmb.2012-0423OC

144. Hirota JA, Hirota SA, Warner SM, Stefanowicz D, Shaheen F, Beck PL, et al. The airway epithelium nucleotide-binding domain and leucine-rich repeat protein 3 inflammasome is activated by urban particulate matter. J Allergy Clin Immunol (2012) 129(4):1116-25. doi:10.1016/j.jaci.2011.11.033

145. Besnard AG, Guillou N, Tschopp J, Erard F, Couillin I, Iwakura Y, et al. NLRP3 inflammasome is required in murine asthma in the absence of aluminum adjuvant. Allergy (2011) 66(8):1047-57. doi:10.1111/j.1398-9995.2011.02586.x

146. Ather JL, Ckless K, Martin R, Foley KL, Suratt BT, Boyson JE, et al. Serum amyloid A activates the NLRP3 inflammasome and promotes Th17 allergic 
asthma in mice. J Immunol (2011) 187(1):64-73. doi:10.4049/jimmunol. 1100500

147. Hitomi Y, Ebisawa M, Tomikawa M, Imai T, Komata T, Hirota T, et al. Associations of functional NLRP3 polymorphisms with susceptibility to foodinduced anaphylaxis and aspirin-induced asthma. J Allergy Clin Immunol (2009) 124(4):779-85. doi:10.1016/j.jaci.2009.07.044

148. Konishi H, Tsutsui H, Murakami T, Yumikura-Futatsugi S, Yamanaka K, Tanaka M, et al. IL-18 contributes to the spontaneous development of atopic dermatitis-like inflammatory skin lesion independently of $\mathrm{IgE} /$ stat6 under specific pathogen-free conditions. Proc Natl Acad Sci US A (2002) 99(17):11340-5. doi:10.1073/pnas.152337799

149. Yoshimoto T, Mizutani H, Tsutsui H, Noben-Trauth N, Yamanaka K, Tanaka $\mathrm{M}$, et al. IL-18 induction of IgE: dependence on CD4+ T cells, IL-4 and STAT6. Nat Immunol (2000) 1(2):132-7. doi:10.1038/77811

150. Dai X, Sayama K, Tohyama M, Shirakata Y, Hanakawa Y, Tokumaru S, et al. Mite allergen is a danger signal for the skin via activation of inflammasome in keratinocytes. J Allergy Clin Immunol (2011) 127(3):806-14. doi:10.1016/j.jaci.2010.12.006

151. Omoto Y, Tokime K, Yamanaka K, Habe K, Morioka T, Kurokawa I, et al. Human mast cell chymase cleaves pro-IL-18 and generates a novel and biologically active IL-18 fragment. J Immunol (2006) 177(12):8315-9.

152. Shornick LP, De Togni P, Mariathasan S, Goellner J, Strauss-Schoenberger J, Karr RW, et al. Mice deficient in IL-1beta manifest impaired contact hypersensitivity to trinitrochlorobenzone. J Exp Med (1996) 183(4):1427-36. doi:10.1084/jem.183.4.1427

153. Watanabe H, Gaide O, Pétrilli V, Martinon F, Contassot E, Roques S, et al. Activation of the IL-1beta-processing inflammasome is involved in contact hypersensitivity. J Invest Dermatol (2007) 127(8):1956-63. doi:10.1038/sj.jid. 5700819

154. Shornick LP, Bisarya AK, Chaplin DD. IL-1beta is essential for Langerhans cell activation and antigen delivery to the lymph nodes during contact sensitization: evidence for a dermal source of IL-1beta. Cell Immunol (2001) 211(2):105-12. doi:10.1006/cimm.2001.1834

155. Antonopoulos C, Cumberbatch M, Dearman RJ, Daniel RJ, Kimber I, Groves RW. Functional caspase-1 is required for Langerhans cell migration and optimal contact sensitization in mice. J Immunol (2001) 166(6):3672-7.

156. Hoeffel G, Wang Y, Greter M, See P, Teo P, Malleret B, et al. Adult Langerhans cells derive predominantly from embryonic fetal liver monocytes with a minor contribution of yolk sac-derived macrophages. J Exp Med (2012) 209(6):1167-81. doi:10.1084/jem.20120340

157. Kissenpfennig A, Malissen B. Langerhans cells - revisiting the paradigm using genetically engineered mice. Trends Immunol (2006) 27(3):132-9. doi:10.1016/ j.it.2006.01.003

158. Watanabe H, Gehrke S, Contassot E, Roques S, Tschopp J, Friedmann PS, et al. Danger signaling through the inflammasome acts as a master switch between tolerance and sensitization. J Immunol (2008) 180(9):5826-32.

159. Sutterwala FS, Ogura Y, Szczepanik M, Lara-Tejero M, Lichtenberger GS, Grant EP, et al. Critical role for NALP3/CIAS1/Cryopyrin in innate and adaptive immunity through its regulation of caspase-1. Immunity (2006) 24(3):317-27. doi:10.1016/j.immuni.2006.02.004

160. Damm A, Lautz K, Kufer TA. Roles of NLRP10 in innate and adaptive immunity. Microbes Infect (2013) 15(6-7):516-23. doi:10.1016/j.micinf.2013.03.008

161. Hirota T, Takahashi A, Kubo M, Tsunoda T, Tomita K, Sakashita M, et al. Genome-wide association study identifies eight new susceptibility loci for atopic dermatitis in the Japanese population. Nat Genet (2012) 44(11):1222-6. doi:10.1038/ng.2438

162. MacAluso F, Nothnagel M, Parwez Q, Petrasch-Parwez E, Bechara FG, Epplen JT, et al. Polymorphisms in NACHT-LRR (NLR) genes in atopic dermatitis. Exp Dermatol (2007) 16(8):692-8. doi:10.1111/j.1600-0625.2007.00589.x

163. Lautz K, Damm A, Menning M, Wenger J, Adam AC, Zigrino P, et al. NLRP10 enhances Shigella-induced pro-inflammatory responses. Cell Microbiol (2012) 14(10):1568-83. doi:10.1111/j.1462-5822.2012.01822.x

164. Hoffman HM, Brydges SD. Genetic and molecular basis of inflammasomemediated disease. J Biol Chem (2011) 286(13):10889-96. doi:10.1074/jbc.R110. 135491

165. Lachmann HJ, Lowe P, Felix SD, Rordorf C, Leslie K, Madhoo S, et al. In vivo regulation of interleukin lbeta in patients with cryopyrin-associated periodic syndromes. J Exp Med (2009) 206(5):1029-36. doi:10.1084/jem.20082481
166. Lachmann HJ, Kone-Paut I, Kuemmerle-Deschner JB, Leslie KS, Hachulla E, Quartier P, et al. Use of canakinumab in the cryopyrin-associated periodic syndrome. N Engl J Med (2009) 360(23):2416-25. doi:10.1056/NEJMoa0810787

167. Brydges SD, Mueller JL, McGeough MD, Pena CA, Misaghi A, Gandhi C, et al. Inflammasome-mediated disease animal models reveal roles for innate but not adaptive immunity. Immunity (2009) 30(6):875-87. doi:10.1016/j.immuni. 2009.05.005

168. Shaw PJ, McDermott MF, Kanneganti TD. Inflammasomes and autoimmunity. Trends Mol Med (2011) 17(2):57-64. doi:10.1016/j.molmed.2010.11.001

169. Ben-Sasson SZ, Hu-Li J, Quiel J, Cauchetaux S, Ratner M, Shapira I, et al. IL-1 acts directly on CD4 T cells to enhance their antigen-driven expansion and differentiation. Proc Natl Acad Sci U S A (2009) 106(17):7119-24. doi:10.1073/pnas.0902745106

170. Chung Y, Chang SH, Martinez GJ, Yang XO, Nurieva R, Kang HS, et al. Critical regulation of early Th17 cell differentiation by interleukin-1 signaling. Immunity (2009) 30(4):576-87. doi:10.1016/j.immuni.2009.02.007

171. Acosta-Rodriguez EV, Napolitani G, Lanzavecchia A, Sallusto F. Interleukins 1beta and 6 but not transforming growth factor-beta are essential for the differentiation of interleukin 17-producing human T helper cells. Nat Immunol (2007) 8(9):942-9. doi:10.1038/ni1496

172. Goverman J. Autoimmune T cell responses in the central nervous system. Nat Rev Immunol (2009) 9(6):393-407. doi:10.1038/nri2550

173. Furlan R, Filippi M, Bergami A, Rocca MA, Martinelli V, Poliani PL, et al. Peripheral levels of caspase-1 mRNA correlate with disease activity in patients with multiple sclerosis; a preliminary study. J Neurol Neurosurg Psychiatry (1999) 67(6):785-8. doi:10.1136/jnnp.67.6.785

174. Huang WX, Huang P, Hillert J. Increased expression of caspase-1 and interleukin-18 in peripheral blood mononuclear cells in patients with multiple sclerosis. Mult Scler (2004) 10(5):482-7. doi:10.1191/1352458504ms1071oa

175. Ming X, Li W, Maeda Y, Blumberg B, Raval S, Cook SD, et al. Caspase-1 expression in multiple sclerosis plaques and cultured glial cells. J Neurol Sci (2002) 197(1-2):9-18. doi:10.1016/S0022-510X(02)00030-8

176. Magalhaes JG, Fritz JH, Le Bourhis L, Sellge G, Travassos LH, Selvanantham T, et al. Nod2-dependent Th2 polarization of antigen-specific immunity. J Immunol (2008) 181(11):7925-35.

177. Furlan R, Martino G, Galbiati F, Poliani PL, Smiroldo S, Bergami A, et al. Caspase-1 regulates the inflammatory process leading to autoimmune demyelination. J Immunol (1999) 163(5):2403-9.

178. Lalor SJ, Dungan LS, Sutton CE, Basdeo SA, Fletcher JM, Mills KH. Caspase-1processed cytokines IL-1beta and IL-18 promote IL-17 production by gammadelta and CD4 T cells that mediate autoimmunity. J Immunol (2011) 186(10):5738-48. doi:10.4049/jimmunol.1003597

179. Sutton C, Brereton C, Keogh B, Mills KH, Lavelle EC. A crucial role for interleukin (IL)-1 in the induction of IL-17-producing T cells that mediate autoimmune encephalomyelitis. J Exp Med (2006) 203(7):1685-91. doi:10.1084/jem. 20060285

180. Gris D, Ye Z, Iocca HA, Wen H, Craven RR, Gris P, et al. NLRP3 plays a critical role in the development of experimental autoimmune encephalomyelitis by mediating Th1 and Th17 responses. J Immunol (2010) 185(2):974-81. doi:10.4049/jimmunol.0904145

181. Jha S, Ting JP. Inflammasome-associated nucleotide-binding domain, leucine-rich repeat proteins and inflammatory diseases. J Immunol (2009) 183(12):7623-9. doi:10.4049/jimmunol.0902425

182. Inoue M, Williams KL, Gunn MD, Shinohara ML. NLRP3 inflammasome induces chemotactic immune cell migration to the CNS in experimental autoimmune encephalomyelitis. Proc Natl Acad Sci USA (2012) 109(26):10480-5. doi:10.1073/pnas.1201836109

183. Shaw PJ, Lukens JR, Burns S, Chi H, McGargill MA, Kanneganti TD. Cutting edge: critical role for PYCARD/ASC in the development of experimental autoimmune encephalomyelitis. J Immunol (2010) 184(9):4610-4. doi:10.4049/jimmunol.1000217

184. Ippagunta SK, Malireddi RK, Shaw PJ, Neale GA, Walle LV, Fukui Y, et al. Addendum: defective Dock2 expression in a subset of ASC-deficient mouse lines. Nat Immunol (2012) 13(7):701-2. doi:10.1038/ni.2389

185. Inoue M, Williams KL, Oliver T, Vandenabeele P, Rajan JV, Miao EA, et al. Interferon-beta therapy against $\mathrm{EAE}$ is effective only when development of the disease depends on the NLRP3 inflammasome. Sci Signal (2012) 5(225):ra38. doi:10.1126/scisignal.2002767 
186. Masters SL, Dunne A, Subramanian SL, Hull RL, Tannahill GM, Sharp FA, et al. Activation of the NLRP3 inflammasome by islet amyloid polypeptide provides a mechanism for enhanced IL-1 $\beta$ in type 2 diabetes. Nat Immunol (2010) 11(10):897-904. doi:10.1038/ni.1935

187. Vandanmagsar B, Youm YH, Ravussin A, Galgani JE, Stadler K, Mynatt RL, et al. The NLRP3 inflammasome instigates obesity-induced inflammation and insulin resistance. Nat Med (2011) 17(2):179-88. doi:10.1038/nm.2279

188. Wen H, Gris D, Lei Y, Jha S, Zhang L, Huang MT, et al. Fatty acid-induced NLRP3-ASC inflammasome activation interferes with insulin signaling. Nat Immunol (2011) 12(5):408-15. doi:10.1038/ni.2022

189. Schott WH, Haskell BD, Tse HM, Milton MJ, Piganelli JD, Choisy-Rossi CM, et al. Caspase- 1 is not required for type 1 diabetes in the NOD mouse. Diabetes (2004) 53(1):99-104. doi:10.2337/diabetes.53.1.99

190. Pontillo A, Brandao L, Guimaraes R, Segat L, Araujo J, Crovella S. Two SNPs in NLRP3 gene are involved in the predisposition to type-1 diabetes and celiac disease in a pediatric population from northeast Brazil. Autoimmunity (2010) 43(8):583-9. doi:10.3109/08916930903540432

191. Magitta NF, Bøe Wolff AS, Johansson S, Skinningsrud B, Lie BA, Myhr $\mathrm{KM}$, et al. A coding polymorphism in NALP1 confers risk for autoimmune Addison's disease and type 1 diabetes. Genes Immun (2009) 10(2):120-4. doi:10.1038/gene.2008.85

192. Moran A, Bundy B, Becker DJ, DiMeglio LA, Gitelman SE, Goland R, et al. Interleukin-1 antagonism in type 1 diabetes of recent onset: two multicentre, randomised, double-blind, placebo-controlled trials. Lancet (2013) 381(9881):1905-15. doi:10.1016/S0140-6736(13)60023-9

193. Nicoletti F, Di Marco R, Barcellini W, Magro G, Schorlemmer HU, Kurrle R, et al. Protection from experimental autoimmune diabetes in the non-obese diabetic mouse with soluble interleukin-1 receptor. Eur J Immunol (1994) 24(8):1843-7. doi:10.1002/eji.1830240818

194. Furst DE, Keystone EC, Braun J, Breedveld FC, Burmester GR, De Benedetti $\mathrm{F}$, et al. Updated consensus statement on biological agents for the treatment of rheumatic diseases, 2011. Ann Rheum Dis (2012) 71(Suppl 2):i2-45. doi:10.1136/annrheumdis-2011-201036

195. Sui J, Li H, Fang Y, Liu Y, Li M, Zhong B, et al. NLRP1 gene polymorphism influences gene transcription and is a risk factor for rheumatoid arthritis in Han Chinese. Arthritis Rheum (2012) 64(3):647-54. doi:10.1002/art.33370

196. Mathews RJ, Robinson JI, Battellino M, Wong C, Taylor JC, Eyre S, et al. Evidence of NLRP3-inflammasome activation in rheumatoid arthritis (RA); genetic variants within the NLRP3-inflammasome complex in relation to susceptibility to RA and response to anti-TNF treatment. Ann Rheum Dis (2013). doi:10.1136/annrheumdis-2013-203276

197. Ippagunta SK, Brand DD, Luo J, Boyd KL, Calabrese C, Stienstra R, et al. Inflammasome-independent role of apoptosis-associated speck-like protein containing a CARD (ASC) in T cell priming is critical for collagen-induced arthritis. J Biol Chem (2010) 285(16):12454-62. doi:10.1074/jbc.M109.093252

198. Kolly L, Karababa M, Joosten LA, Narayan S, Salvi R, Pétrilli V, et al. Inflammatory role of ASC in antigen-induced arthritis is independent of caspase-1, NALP-3, and IPAF. J Immunol (2009) 183(6):4003-12. doi:10.4049/jimmunol. 0802173

199. Nickerson KM, Christensen SR, Shupe J, Kashgarian M, Kim D, Elkon K, et al. TLR9 regulates TLR7- and MyD88-dependent autoantibody production and disease in a murine model of lupus. J Immunol (2010) 184(4):1840-8. doi:10.4049/jimmunol.0902592

200. Shin MS, Kang Y, Lee N, Wahl ER, Kim SH, Kang KS, et al. Self double-stranded (ds)DNA induces IL-1beta production from human monocytes by activating NLRP3 inflammasome in the presence of anti-dsDNA antibodies. J Immunol (2013) 190(4):1407-15. doi:10.4049/jimmunol.1201195

201. Zhang W, Cai Y, Xu W, Yin Z, Gao X, Xiong S. AIM2 facilitates the apoptotic DNA-induced systemic lupus erythematosus via arbitrating macrophage functional maturation. J Clin Immunol (2013) 33(5):925-37. doi:10.1007/s10875013-9881-6

202. Voronov E, Dayan M, Zinger H, Gayvoronsky L, Lin JP, Iwakura Y, et al. IL-1 beta-deficient mice are resistant to induction of experimental SLE. Eur Cytokine Netw (2006) 17(2):109-16.

203. Pontillo A, Girardelli M, Kamada AJ, Pancotto JA, Donadi EA, Crovella S, et al. Polimorphisms in inflammasome genes are involved in the predisposition to systemic lupus erythematosus. Autoimmunity (2012) 45(4):271-8. doi:10.3109/08916934.2011.637532
204. Jin Y, Mailloux CM, Gowan K, Riccardi SL, LaBerge G, Bennett DC, et al. NALP1 in vitiligo-associated multiple autoimmune disease. $N$ Engl J Med (2007) 356(12):1216-25. doi:10.1056/NEJMoa061592

205. Dieudé P, Guedj M, Wipff J, Ruiz B, Riemekasten G, Airo P, et al. NLRP1 influences the systemic sclerosis phenotype: a new clue for the contribution of innate immunity in systemic sclerosis-related fibrosing alveolitis pathogenesis. Ann Rheum Dis (2011) 70(4):668-74. doi:10.1136/ard.2010.131243

206. Zurawek M, Fichna M, Januszkiewicz-Lewandowska D, Gryczynska M, Fichna P, Nowak J. A coding variant in NLRP1 is associated with autoimmune Addison's disease. Hum Immunol (2010) 71(5):530-4. doi:10.1016/j.humimm. 2010.02.004

207. Saijo Y, Tanaka M, Miki M, Usui K, Suzuki T, Maemondo M, et al. Proinflammatory cytokine IL-1 beta promotes tumor growth of Lewis lung carcinoma by induction of angiogenic factors: in vivo analysis of tumor-stromal interaction. J Immunol (2002) 169(1):469-75.

208. Krelin Y, Voronov E, Dotan S, Elkabets M, Reich E, Fogel M, et al. Interleukin1beta-driven inflammation promotes the development and invasiveness of chemical carcinogen-induced tumors. Cancer Res (2007) 67(3):1062-71. doi: 10.1158/0008-5472.CAN-06-2956

209. Voronov E, Shouval DS, Krelin Y, Cagnano E, Benharroch D, Iwakura Y, et al. IL-1 is required for tumor invasiveness and angiogenesis. Proc Natl Acad Sci U S A (2003) 100(5):2645-50. doi:10.1073/pnas.0437939100

210. Lavi G, Voronov E, Dinarello CA, Apte RN, Cohen S. Sustained delivery of IL-1 Ra from biodegradable microspheres reduces the number of murine B16 melanoma lung metastases. J Control Release (2007) 123(2):123-30. doi:10.1016/j.jconrel.2007.07.015

211. Zaki MH, Vogel P, Malireddi RK, Body-Malapel M, Anand PK, Bertin J, et al. The NOD-like receptor NLRP12 attenuates colon inflammation and tumorigenesis. Cancer Cell (2011) 20(5):649-60. doi:10.1016/j.ccr.2011.10.022

212. Hu B, Elinav E, Huber S, Booth CJ, Strowig T, Jin C, et al. Inflammationinduced tumorigenesis in the colon is regulated by caspase-1 and NLRC4. Proc Natl Acad Sci U S A (2010) 107(50):21635-40. doi:10.1073/pnas.1016814108

213. Normand S, Delanoye-Crespin A, Bressenot A, Huot L, Grandjean T, PeyrinBiroulet L, et al. Nod-like receptor pyrin domain-containing protein 6 (NLRP6) controls epithelial self-renewal and colorectal carcinogenesis upon injury. Proc Natl Acad Sci U S A (2011) 108(23):9601-6. doi:10.1073/pnas. 1100981108

214. Zaki MH, Vogel P, Body-Malapel M, Lamkanfi M, Kanneganti TD. IL-18 production downstream of the Nlrp3 inflammasome confers protection against colorectal tumor formation. J Immunol (2010) 185(8):4912-20. doi:10.4049/ jimmunol.1002046

215. Terme M, Ullrich E, Aymeric L, Meinhardt K, Desbois M, Delahaye N, et al. IL18 induces PD-1-dependent immunosuppression in cancer. Cancer Res (2011) 71(16):5393-9. doi:10.1158/0008-5472.CAN-11-0993

216. Ménard C, Martin F, Apetoh L, Bouyer F, Ghiringhelli F. Cancer chemotherapy: not only a direct cytotoxic effect, but also an adjuvant for antitumor immunity. Cancer Immunol Immunother (2008) 57(11):1579-87. doi:10.1007/ s00262-008-0505-6

217. Ghiringhelli F, Apetoh L, Tesniere A, Aymeric L, Ma Y, Ortiz C, et al. Activation of the NLRP3 inflammasome in dendritic cells induces IL-1betadependent adaptive immunity against tumors. Nat Med (2009) 15(10):1170-8. doi: $10.1038 / \mathrm{nm} .2028$

218. van Deventer HW, Burgents JE, Wu QP, Woodford RM, Brickey WJ, Allen IC, et al. The inflammasome component NLRP3 impairs antitumor vaccine by enhancing the accumulation of tumor-associated myeloid-derived suppressor cells. Cancer Res (2010) 70(24):10161-9. doi:10.1158/0008-5472.CAN-101921

219. Tu S, Bhagat G, Cui G, Takaishi S, Kurt-Jones EA, Rickman B, et al. Overexpression of interleukin-lbeta induces gastric inflammation and cancer and mobilizes myeloid-derived suppressor cells in mice. Cancer Cell (2008) 14(5):408-19. doi:10.1016/j.ccr.2008.10.011

220. Bruchard M, Mignot G, Derangère V, Chalmin F, Chevriaux A, Végran F, et al. Chemotherapy-triggered cathepsin B release in myeloid-derived suppressor cells activates the Nlrp3 inflammasome and promotes tumor growth. Nat Med (2013) 19(1):57-64. doi:10.1038/nm.2999

221. Zitvogel L, Apetoh L, Ghiringhelli F, Kroemer G. Immunological aspects of cancer chemotherapy. Nat Rev Immunol (2008) 8(1):59-73. doi:10.1038/ nri2216 
222. Garaude J, Kent A, van Rooijen N, Blander JM. Simultaneous targeting of tolland nod-like receptors induces effective tumor-specific immune responses. Sci Transl Med (2012) 4(120):120ra16. doi:10.1126/scitranslmed.3002868

223. Qin J, Li R, Raes J, Arumugam M, Burgdorf KS, Manichanh C, et al. A human gut microbial gene catalogue established by metagenomic sequencing. Nature (2010) 464(7285):59-65. doi:10.1038/nature08821

224. Ivanov II, Honda K. Intestinal commensal microbes as immune modulators. Cell Host Microbe (2012) 12(4):496-508. doi:10.1016/j.chom.2012.09. 009

225. Tanoue T, Honda K. Induction of Treg cells in the mouse colonic mucosa: a central mechanism to maintain host-microbiota homeostasis. Semin Immunol (2012) 24:50-7. doi:10.1016/j.smim.2011.11.009

226. Ivanov II, Atarashi K, Manel N, Brodie EL, Shima T, Karaoz U, et al. Induction of intestinal Th17 cells by segmented filamentous bacteria. Cell (2009) 139(3):485-98. doi:10.1016/j.cell.2009.09.033

227. Kamada N, Seo SU, Chen GY, Núñez G. Role of the gut microbiota in immunity and inflammatory disease. Nat Rev Immunol (2013) 13(5):321-35. doi:10.1038/nri3430

228. Hugot JP, Chamaillard M, Zouali H, Lesage S, Cézard JP, Belaiche J, et al. Association of NOD2 leucine-rich repeat variants with susceptibility to Crohn's disease. Nature (2001) 411(6837):599-603. doi:10.1038/35079107

229. Villani AC, Lemire M, Fortin G, Louis E, Silverberg MS, Collette C, et al. Common variants in the NLRP3 region contribute to Crohn's disease susceptibility. Nat Genet (2008) 41(1):71-6. doi:10.1038/ng.285

230. Zaki MH, Boyd KL, Vogel P, Kastan MB, Lamkanfi M, Kanneganti TD. The NLRP3 inflammasome protects against loss of epithelial integrity and mortality during experimental colitis. Immunity (2010) 32(3):379-91. doi:10.1016/j. immuni.2010.03.003

231. Huber S, Gagliani N, Zenewicz LA, Huber FJ, Bosurgi L, Hu B, et al. IL-22BP is regulated by the inflammasome and modulates tumorigenesis in the intestine. Nature (2012) 491(7423):259-63. doi:10.1038/nature11535

232. Ichinohe T, Pang IK, Kumamoto Y, Peaper DR, Ho JH, Murray TS, et al. Microbiota regulates immune defense against respiratory tract influenza A virus infection. Proc Natl Acad Sci U S A (2011) 108(13):5354-9. doi:10.1073/pnas. 1019378108

Conflict of Interest Statement: The authors declare that the research was conducted in the absence of any commercial or financial relationships that could be construed as a potential conflict of interest.

Received: 13 September 2013; paper pending published: 30 October 2013; accepted: 10 December 2013; published online: 27 December 2013.

Citation: Liu D, Rhebergen AM and Eisenbarth SC (2013) Licensing adaptive immunity by NOD-like receptors. Front. Immunol. 4:486. doi: 10.3389/fimmu.2013.00486 This article was submitted to Molecular Innate Immunity, a section of the journal Frontiers in Immunology.

Copyright (C) 2013 Liu, Rhebergen and Eisenbarth. This is an open-access article distributed under the terms of the Creative Commons Attribution License (CC BY). The use, distribution or reproduction in other forums is permitted, provided the original author(s) or licensor are credited and that the original publication in this journal is cited, in accordance with accepted academic practice. No use, distribution or reproduction is permitted which does not comply with these terms. 